\title{
Aggasztó tendenciák az Európai Unió munkaeröpiacán
}

\section{Artner Annamária,}

az MTA Közgazdaságés Regionális Tudományi Kutatóközpont Világgazdasági Intézetének tudományos főmunkatársa

E-mail:

artner.annamaria@krtk.mta.hu
A cikk statisztikai adatok alapján átfogó képet nyújt arról, hogy különösen az ezredforduló óta miként változott az EU (Európai Unió) munkaerőpiaca. A foglalkoztatás és a munkanélküliség mellett a különféle atipikus foglalkoztatási formák és a munkaerőpiaci szegénység alakulását vizsgálja. A szerző ezeken túl bemutatja az EU szociális és foglalkoztatáspolitikai eszközeinek fejlődését is, és szembeállítja azt a munkaerőpiaci jelenségekkel. Az áttekintésből kitünik, hogy az EU munkaerőpiaca az elmúlt évtizedekben jelentősen differenciálódott, és az atipikus foglalkoztatási formák térnyerésével megjelent egy helyenként még látens, másutt már nagyon is érzékelhető elszegényedő, bizonytalan és kiszolgáltatott helyzetben levő társadalmi réteg. Az európai munkaerőpiacnak ezt a ma még elhanyagolhatónak tünő, ám aggasztóan terjedő romlását a közösségi politikák, bár megállítani nem tudták, eddig képesek voltak fékezni.

TÁRGYSZÓ:

Európai Unió.

Munkaerőpiac.

Szociális helyzet.

DOI: 10.20311/stat2018.04.hu0341 
$\mathrm{N}_{\text {apjainkban az EU minden jel szerint mérföldkő előtt áll. Sokféle válsággóccal }}$ és kihívással kell szembenéznie, melyek közül az egyik leglényegesebb a munkaerőpiac alakulása, nevezetesen azok az 1990-es évek óta megfigyelhető és a keleti kibövüléssel, majd a 2008-as válsággal eszkalálódó, a foglalkoztatást és ennek nyomán az emberek szociális helyzetét érintő negatív tendenciák, melyek enyhítésére talán igen, de visszafordítására egyelöre nem sok remény látszik.

Az EGK-ban (Európai Gazdasági Közösség ${ }^{1}$ ) a munkavállalók alapjogait közösségi szinten elöször a Munkavállalók Alapvető Szociális Jogairól szóló Közösségi Chartában (Commission of the European Communities [1990]), 1989-ben szabályozták. Majd bő egy évtized múlva, 2000-ben, az EU Alapjogi Chartájában (Official Journal of the European Communities [2000]) fektették le az „európai szociális modell" alapelveit, melynek intézményi feltételeit a Lisszaboni Szerződés (Az Európai Unió Hivatalos Lapja [2007]) igyekezett megteremteni. Ezután következett be a 2008. évi válság, és az európai polgárok EU-ba vetett bizalma - tovább - csökkent (EC [2017b] 14. old.). Az egyenlötlenségek és az ellentétek, melyek többek között a válságkezelésre alkalmazott és a költségvetési egyensúlyra koncentráló megszorító politikák miatt jelentek meg és erősödtek fel, azzal fenyegettek, hogy a szociális dimenzió megszilárdítása nélkül az Európai Unió összeomolhat. 2015. szeptember 6-án, ironikus módon alig néhány héttel azután, hogy az Európai Bizottság (továbbiakban Bizottság) Görögországot a szociális és a jóléti kiadások további csökkentésével járó harmadik pénzügyi mentócsomag elfogadására kényszerítette, a Bizottság elnöke, Jean-Claude Juncker egy „fair” összeurópai munkaerőpiac megteremtését, a „szociális jogok európai pillérének” kidolgozását indítványozta.

Az ezt követő konzultációk és viták eredményeképpen az Európai Parlament, a Tanács és a Bizottság a 2017. november 17-én, Göteborgban tartott, tisztességes munkafeltételekről és növekedésről szóló szociális csúcstalálkozón ${ }^{2}$ hirdette ki a szociális jogok európai pillérét (EP-Tanács-EB [2017]), amely, kitérve a következő kérdésekre, húsz alapelvben összegzi az egyenlő munkaerőpiaci esélyekre, a fair munkakörülményekre, valamint a szociális védelemre és a társadalmi integrációra vonatkozó jogokat,: 1 . oktatás, képzés és egész életen át tartó tanulás, 2. nemek közötti és 3. esélyegyenlöség, 4. a foglalkoztatás aktív támogatása, 5. biztonságos és rugalmas foglalkoztatás, 6 . bérek, 7. tájékoztatás a munkaviszony feltételeiröl és védelem elbocsátás esetén, 8 . szociális párbeszéd és munkavállalói részvétel, 9. a munka és a magánélet egyensúlya, 10. egészséges, biztonságos, megfelelően kialakí-

\footnotetext{
${ }^{1}$ A maastrichti szerződés 1993. november 1-jei hatályba lépését követően EU.

${ }^{2}$ A csúcstalálkozó zárójelentéséért lásd EC-GOS [2017].
} 
tott munkakörnyezet és adatvédelem, 11 . gyermekgondozás és a gyermekek támogatása, 12. szociális védelem, 13. munkanélküli-járadék, 14. minimumjövedelem, 15. időskori jövedelem és öregségi nyugdíjak, 16. egészségügyi ellátás, 17. a fogyatékossággal élő személyek társadalmi befogadása, 18. tartós ápolás-gondozás, 19. lakhatás és segítségnyújtás a hajléktalanok számára, illetve 20. alapvető szolgáltatásokhoz (víz, közlekedés, kommunikáció stb.) való hozzáférés. Az EP-Tanács-EB [2017] nem kötelező érvényü jogszabály, csak egy deklaráció, amely azonban kifejezi az EU mind a 27 aktív tagjának szándékát.

Mindez indokolttá teszi, hogy - a téma gazdagságára és a jelen tanulmány terjedelme által szabott korlátokra tekintettel a teljesség igénye nélkül - áttekintést adjunk az európai munkaeröpiacról, és objektív statisztikai adatokra támaszkodva bemutassuk az ezredforduló óta eltelt időszak legjellemzőbb tendenciáit. A munkaerőpiaci folyamatokat részleteikben feltáró empirikus tanulmányok rendszerint nagy különbségeket találnak a különböző munkaerőpiaci szegmensek, illetve a tagországok között, és nem kevésbé sokszínúek a folyamatok mögött meghúzódó gazdasági, szerkezeti és intézményi jellemzők sem. Ezért, ha a meghatározó tendenciákat szeretnénk azonosítani, aggregált adatokra kell hagyatkoznunk. Ez az eljárás ugyan a részkérdésekről csak elnagyolt, az európai munkaerőpiac fő folyamatairól átfogó képet nyújt. Mindazonáltal, ahol lehet és szükséges, igyekszünk rávilágítani a regionális vagy korcsoportos jellemzőkre is, de nem elemezzük a 28 tagország egyedi sajátosságait.

A következőkben tehát elsősorban az Eurostat adataira támaszkodva azt vizsgáljuk, hogy miként változtak az EU munkaerőpiacának fö jellemzői a 2000-es évek elejétől napjainkig. Így áttekintjük a foglalkoztatás és a munkanélküliség alakulását és korcsoportos jellemzöit, a különböző atipikus foglalkoztatási formákat, valamint a munkaerőpiaccal összefüggő szegénység egyes dimenzióit. Végezetül felvázoljuk, hogy közösségi szinten az EU milyen lépéseket tett az 1970-es évek óta a munkaerópiaci és a szociális feszültségek oldásáért az e célt szolgáló uniós pénzalapokon keresztül.

\section{Foglalkoztatás}

Világszintủ összehasonlításban az EU kimagaslóan fejlettnek és széles körünek mondható jóléti rendszereiről híres. Ezeket úgy Nyugat-, mint Kelet-KözépEurópában az 1970-es évekig fejlesztették ki. Azt követően a rendszerek „,konszolidálódtak", majd az utóbbi néhány évtizedben - ha máskor nem is, de a 2008-as válságot követö megszorítások idején mindenképpen - a juttatások mértékét, feltételeit és hatókörét tekintve többnyire zsugorodtak, illetve szigorodtak. Ez pedig kihat(ott) a foglalkoztatási viszonyokra. 
Mivel a jólét növekedése következtében az emberek egyre tovább élnek, a születendő gyermekek száma pedig egyre csökken, a jóléti rendszerek szükülése legelöször talán a nyugdíjrendszerek változásában érhető tetten. 2001 és 2016 között a munkában töltött évek átlagos száma, illetve - Románia és Görögország kivételével - az 55-64 éves korosztály foglalkoztatási rátája minden tagországban növekedett (Eurostat [2018a], [2018b]). A helyzet romlása azonban még az ennél idősebbeket is a munkaerőpiacon tartja. 2004 és 2016 között például 3,3 millióról 5,3 millióra nőtt azoknak a 65 éven felülieknek a száma (és 4,2-ről 5,6 százalékra az aránya), akik munkát vállaltak. A $65-69$ éves korosztályban minden nyolcadik ember $(12,1 \%)$ volt ilyen 2016-ban (míg 2004-ben még csak 8,5 százalék) (Eurostat [2018c]).

Ugyanakkor tanulságos, hogy azokban az országokban dolgoznak a leghosszabb ideig, ahol a jóléti rendszerek a legfejlettebbek: az első hat helyet Svédország, Hollandia, Dánia, az Egyesült Királyság, Németország és Finnország foglalja el. Ezeken a helyeken egyrészt a hosszú munkaévek finanszírozhatóvá teszik a jólétet, másrészt a jólét (egészségügy, oktatás stb.) fejlettsége lehetővé teszi, hogy az időskort munkával tölthessék az emberek. Mégis hangsúlyozni kell, hogy a nyugdíjkorhatárok és a teljes nyugdíjra jogosító évek számának emelése, valamint a nyugdíjak relatív értékének csökkentése (Carone et al. [2016]) még akkor is jóléti visszaesést eredményez, ha az idős emberek munkaképessége kitolódik. A munka és a bérmunka nem azonos fogalmak, mint ahogy időskorban munkaképesnek vagy bérmunkára kötelezettnek lenni is lényegesen különböző dolgot jelent. A 2012. évi munkaerő-felmérés kimutatta, hogy bár a munkavállalás indokai sokfélék, az európai idősek túlnyomó többsége (az 50-69 évesek 63 százaléka, a 65-69 évesek több mint fele) anyagi okok miatt dolgozik (Dubois [2016]). Ehhez még azt is hozzá kell tenni, hogy az EU-ban az egészséges életévek átlagos száma 61,5 év volt 2013-ban (Eurostat [2015]), 0,7 évvel kevesebb (!), mint 2010-ben. ${ }^{3}$

Bár 2000 és 2016 között a 15-64 évesek foglalkoztatási rátája a tagországok többségében nőtt (Görögország, Románia, Ciprus, Írország, Portugália és Dánia kivételével, ahol csökkent), mégis 70 százalék alatt maradt. (Lásd az 1. ábrát.) E növekedést elsősorban az 55-64 éves korosztály, másrészröl a nők fokozott munkavállalása magyarázza. (Lásd a 2. ábrát.)

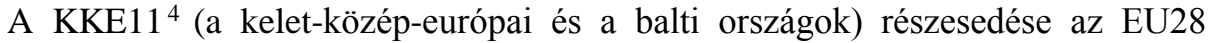
együttes munkaerőpiacából lényegében változatlan, alig több mint 20 százalék körüli. Nem úgy, mint a közösségi GDP-ből való részesedése, ami 2001 és 2008 között 5,1ről 8 százalékra nőtt, s azóta is ekörül stagnál. ${ }^{5}$ Ez egyrészt arra utal, hogy a régióban folyó termelés sokkal munkaigényesebb, mint a fejlettebb tagországokban (beleértve

\footnotetext{
${ }^{3}$ Saját számítás az Eurostat [2018d], [2018e] alapján.

${ }^{4}$ KKE11: Bulgária, Csehország, Észtország, Horvátország, Lengyelország, Lettország, Litvánia, Magyarország, Románia, Szlovákia, Szlovénia.

${ }^{5}$ Saját számítás az Eurostat [2018y] alapján.
} 
az EU déli és észak-nyugati perifériájának, a DÉNY7-nek ${ }^{6}$ az átlagát is), másrészt arra, hogy a régió termelési hatékonyságot (a GDP/foglalkoztatott arányt) érintő felzárkózása az EU többi tagországához a válság óta megtorpant.

1. ábra. A 15-64 évesek foglalkoztatási rátája az EU28-ban, 2000, 2016

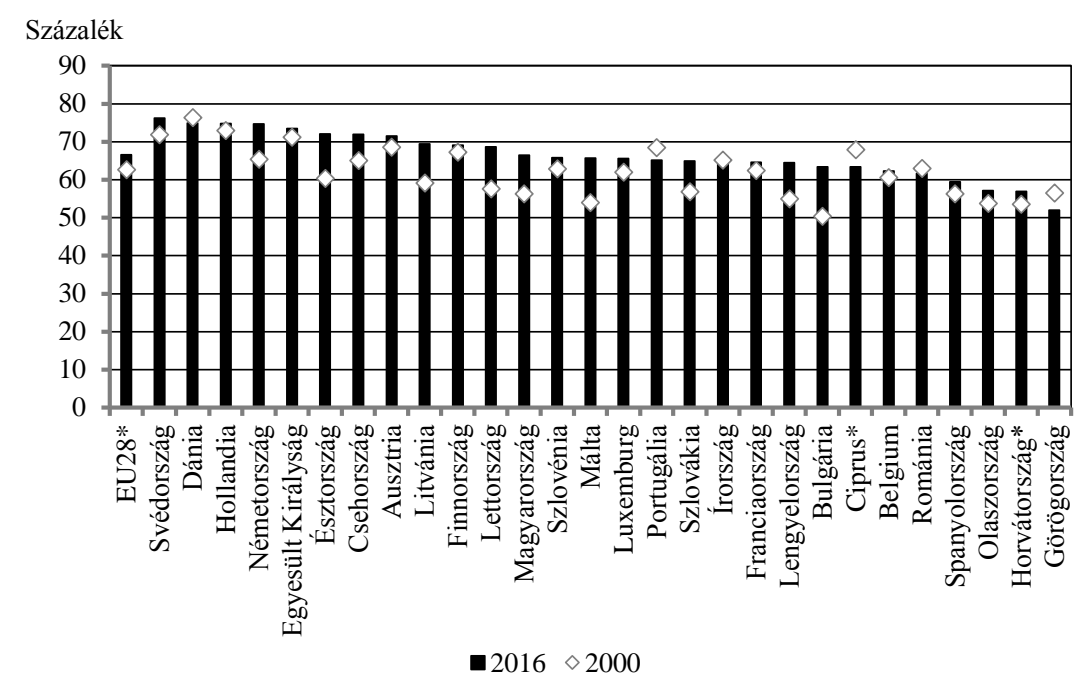

* 2000 helyett Horvátország esetében 2003, EU28 és Ciprus esetében 2001.

Megjegyzés. Itt és a továbbiakban EU28 az Európai Unió 28 tagországát jelenti.

Forrás: Eurostat [2018b].

2. ábra. A 15-64 éves foglalkoztatottak számának változása az EU28-ban nemenként

és korcsoportonként, 2000-2016

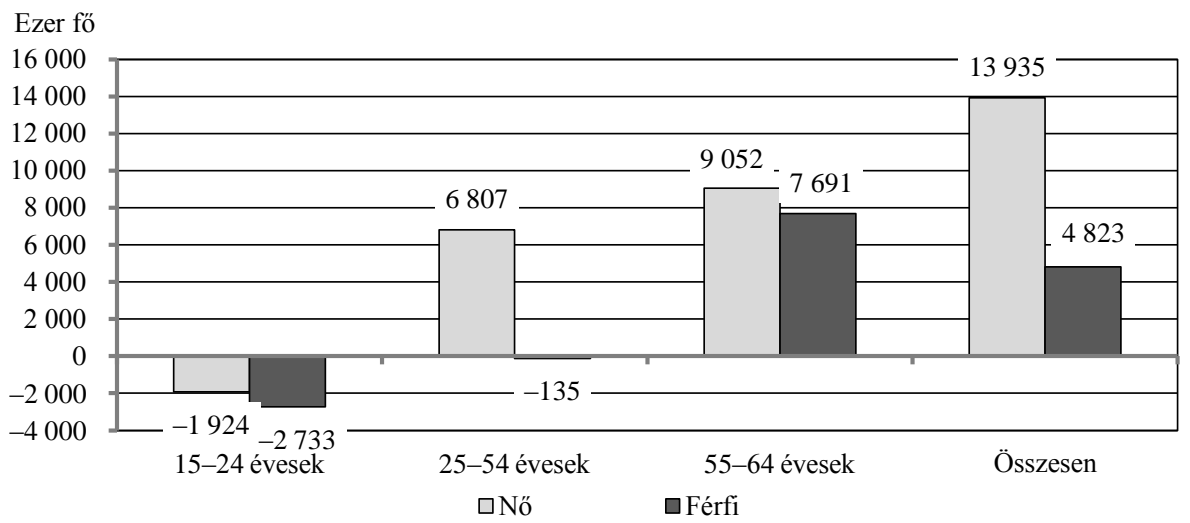

Megjegyzés. Horvátország és Ciprus 2000-es adataira saját becslés.

Forrás: Saját számítás az Eurostat [2018b] alapján.

${ }^{6}$ DÉNY7: Ciprus, Görögország, Írország, Málta, Olaszország, Portugália, Spanyolország. 
A foglalkoztatás mértékének előbbiekben jelzett növekedése a munkafeltételek minőségi romlásával járt (lásd még a 3. és a 4. fejezetet), és elsősorban az atipikus (főként a részmunkaidős, határozott idejü) szerződések számának emelkedéséből adódott. Az EU átlagában nőtt az alacsony keresetűek aránya is, ami föleg a legfejlettebb tagországokban zajló folyamatokkal függ össze.

Idetartozik az is, hogy 2010 és 2015 között 5,9-ről 6,6 százalékra változott a foglalkoztatottak körében azoknak az aránya, akik az adott évben fizikai, mentális vagy szexuális erőszaknak voltak kitéve foglalkoztatási viszonyukban. E mutató értéke a fiatalok körében volt magasabb (2015-ben 6,9 százalék), de az idősek esetén is növekedett (Eurofound [2018]). (Témánk szempontjából természetesen mindegy, hogy ez a válság következménye-e. Hiszen miért lenne megnyugtató, hogy a tőkeértékesülés válsága okozta negatív hatások - amelyekért a dolgozók nem felelnek - a bérmunkát még ilyen formában is utolérik.)

Az EU lépéseit a közösségi/megosztásos gazdaságban müködő egyes cégek (például a személyszállító Uber vagy az ételkihordó Deliveroo) megzabolázására (az évi rendes szabadságot, a munkanélküli-ellátást, az alkalmazottaknak járó betegbiztosítást stb. illetően) éppen az inspirálta, hogy az uniós intézményeket egyre többen kritizálták azért, hogy nem védik eléggé az európai dolgozókat (Aldermanoct [2017]). E témát a legsérülékenyebb munkaerőpiaci csoportokkal foglalkozó 5. fejezetben bővebben tárgyaljuk majd.

\section{Munkanélküliség}

A munkanélküliség Európában az 1970-es években bekövetkezett válság idején „ugrott meg”: az EU15-ben7 1974-ig három százalék alatt volt, az 1980-as évektől kezdve azonban a 7-11 százalékos sávban ingadozott. A mutató az ezredforduló után hullámzóan alakult. 2004-ig, az EU legnagyobb kibővítésének évéig nőtt, később jelentősen csökkent, és mélypontját 2008-ban érte el (16,8 millió fö, 7,2 százalék). A válságot emelkedés követte, ami 2013-ban tetőzött (26,3 millió fö, 10,9 százalék). Majd 2017-ben a munkanélküliségi ráta 7,8 százalékra esett vissza, az állástalanok száma pedig valamivel kevesebb mint 19 millióra. Ez egy százalékponttal és bő egymillió fővel kevesebb a 2000. évinél, ám rosszabb, mint a válság elötti években volt.

\footnotetext{
${ }^{7}$ Az Eurostat az EGK-hoz/EU-hoz az 1970-es évek után csatlakozott tagországok adatait is közli visszamenőleg. EU15: Belgium, Franciaország, Hollandia, Luxemburg, Németország, Olaszország (az EGK alapító országai); Dánia, Egyesült Királyság, Írország (1973-tól); Görögország (1981-től); Portugália, Spanyolország (1986-tól); Ausztria, Finnország és Svédország (1995-től).
} 
A 2000-hez viszonyított javulásnak elsősorban az az oka, hogy a 2004-ben EUhoz csatlakozott tagországokban fellendült a termelés, és ezért nőtt a munkaerökereslet is. A KKE11 körében 2000 és 2016 között a munkanélküliség a felére esett vissza (bár a válság utáni években esetükben is volt emelkedés), s ezzel a KKE11 rezidensek aránya is jelentősen (30 százalék feletti szintről 2016-ra 15 százalékra) mérséklödött az EU állástalan népességén belül. ${ }^{8} \mathrm{E}$ trendek magyarázata részben a termelés kevésbé automatizált, ezért munkaintenzívebb fázisainak az EU keleti perifériájára telepítésében, részben a Keletről Nyugatra irányuló munkavállalási célú migrációban, részben pedig (például Magyarországon) az állam által szervezett közmunkákban rejlik. A kelet-közép-európai munkaerőt nagyon szívesen foglalkoztatják a nyugat-európai munkáltatók, hiszen általában minimálbér-közeli bérért is hajlandók dolgozni, miközben munkájukkal foglalkoztatóik többnyire elégedettek lehetnek. Egy felmérés szerint (EC [2016]) az EU-ban a keleti tagországokból érkezők 1,78szor (a nyugat-európai országokból érkezők 1,3-szor) könnyebben találnak munkát, mint a fogadóország natív munkanélküli lakosai. Az EU-n kívülről érkezők esetén viszont épp fordított a helyzet.

A munkanélküliek legnagyobb részét a 25-74 éves korosztály adja, akiknek többsége a 2008-as válságig az EU tíz legerősebb gazdaságának (továbbiakban Mag10nek) ${ }^{9}$ volt a lakója, azt követően azonban a déli perifériák (elsősorban Spanyolország, Portugália és Görögország) ,vették át ezt a szerepet”.

Európában az 1970-es évek óta magasabb a munkanélküliség, mint az Egyesült Államokban vagy Japánban (s ugyanez igaz a 15-24 éveseket érintő, ún. ifjúsági munkanélküliségre is). Az EU28 és az EU19 (az eurózóna mai 19 tagországának) ${ }^{10}$ átlagos munkanélküliségi rátája már 2000-ben is körülbelül kétszerese volt e két fejlett nem uniós országénak. A 2008-as válság hatására ugyan közeledtek egymáshoz a mutatók, de az azt követő periódusban az Egyesült Államokkal és Japánnal szemben Európa ismét jelentős - az utóbbi esetén egyre növekvő - lemaradást „produkált”: 2016-ban az EU28 munkanélküliségi rátája 8,6, az EU19-é 10 százalék volt, míg az Egyesült Államoké csak 4,9, Japáné pedig 3,1 százalék (Eurostat [2018f]).

2016-ban a Mag10-ben 4,4 millió, a KKE11-ben 3,9 millió, a DÉNY7-ben viszont több mint 8 millió 25 évesnél idősebb munkanélküli élt (Eurostat [2018f]).

Az idősebb emberek munkanélküliségénél jelentősebb probléma az ifjúsági munkanélküliség, hiszen, aki iskola után nem talál elvárásainak, képességeinek megfelelő munkát, az a későbbiekben nagyobb eséllyel kerül a „lecsúszott”, illetve kirekesztés-

\footnotetext{
${ }^{8}$ Saját számítás az Eurostat [2018f] alapján.

${ }^{9}$ Mag10: Ausztria, Belgium, Dánia, Egyesült Királyság, Finnország, Franciaország, Hollandia, Luxemburg, Németország, Svédország.

${ }^{10}$ Idetartoznak a „Hatok” (az EGK alapító országai: Belgium, Franciaország, Hollandia, Luxemburg, Németország, Olaszország), a mediterrán „Hármak” (Görögország, Portugália, Spanyolország), két északi fejlett ország (Finnország, Írország), a „Baltiak” (Észtország, Lettország, Litvánia), három közép-európai ország (Ausztria, Szlovákia, Szlovénia) és a két földközi-tengeri sziget (Ciprus és Málta).
} 
sel fenyegetett társadalmi rétegek közé (Scarpetta-Sonnet-Manfredi [2010]). Hangsúlyozni kell azonban, hogy ez nem függetleníthető a munkaerőpiac általános állapotától (Clark-Summers [1978], O’Higgins [2001]), sőt épp ellenkezőleg: a kapitalizmust jellemző foglalkoztatás általános problémájának a része, illetve a konjunkturális ingadozások következménye (Clark-Summers [1978], O'Higgins [1997]). A fiatalok az újonnan munkaerőpiacra lépők, így a foglalkoztatás bővülése vagy szükülése legelöször az ő felvételüket érinti (első esetben nő a felvételek száma, másodikban elöször az áll le). Ezért az ifjúsági munkanélküliség kérdése nem érthető és nem kezelhető kielégítően a munkaerőpiac általános kihívásainak, illetve azok okainak megértése, hatékony kezelése nélkül (Artner [2013a], [2013b]).

Az EU28 ifjúsági munkanélküliségi rátája az elmúlt közel két évtizedben 20 százalék körül ingadozott, a válságot követően, 2012-ben és 2013-ban 23 százalék fölé ugrott, 2016-ban pedig 18,7 százalékot tett ki. (Lásd a 3. ábrát.) 2017 folyamán a csökkenés tovább folytatódott, s így a 25 éven aluliak munkanélküliségi rátája 2017 májusában már csak 16,9 százalékot ért el. Az eurózóna a magas spanyol és görög értékek miatt ennél nagyobb ifjúsági munkanélküliségtől szenved: a 19 ország átlaga 2017. májusban 18,9 százalékon állt.

3. ábra. A 15-24 évesek munkanélküliségi rátája, 2000-2016

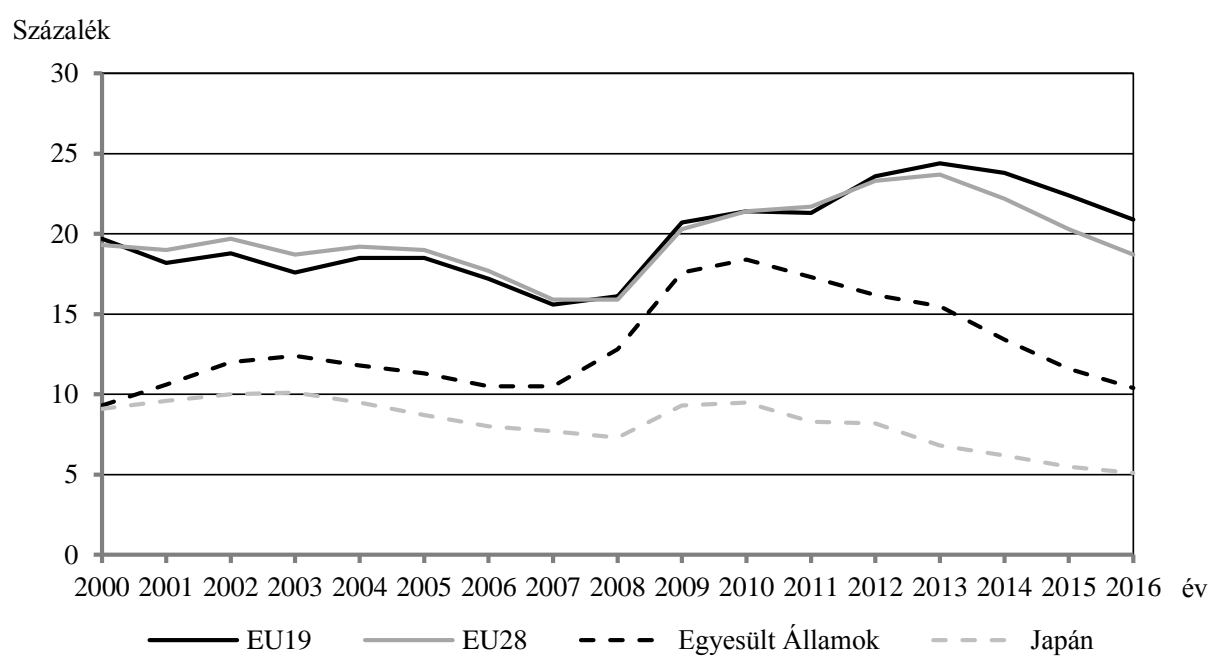

Megjegyzés. Itt és a továbbiakban EU19 a 19 tagú eurózónát jelenti.

Forrás: Eurostat [2018f].

Ha országcsoportonként vizsgáljuk a fiatalok munkaerőpiaci helyzetét, érdekes eredményre jutunk. Bár a fejlett Mag10 esetében jellemzően jóval alacsonyabb a fiatalok munkanélküliségi rátája, az elmúlt évek trendjei a többi országcsoportban is 
gyors javulást mutatnak. A KKE11-ben a válság átmeneti negatív hatása ellenére a 25 évesnél fiatalabb munkanélküliek száma 2000 és 2016 között jelentősen, közel egyharmadára esett vissza. Szintén csökkent az ifjúsági munkanélküliség a válságig a DÉNY7-ben, utána viszont megugrott, de 2016-ban így is kisebb volt, mint 2000ben. A Mag10-ben ugyan már a válság előtti években sem volt érdemben alacsonyabb az ifjúsági munkanélküliség szintje a többi tagországéhoz képest, 2008-at követően nagymértékben emelkedett, s csak 2014-től javult jelentősen. Az utóbbi eredményeképpen ezekben a tagországokban a 25 évesnél fiatalabb munkanélküliek száma 2,1 millióra csökkent, ami azonban csak pár százezerrel kevesebb, mint 2000-ben volt.

Ennek megfelelöen a 25 éven aluliak aránya a munka nélküli népesség körében 2000-hez viszonyítva csökkenést mutat a KKE11-ben és a DÉNY7-ben, miközben a Mag10 esetében éppen hogy növekszik. E tíz gazdag és fejlett ország mutatóinak átlaga a 2008-as válságig nőtt, és csak 2012-t követően mérséklődött, de úgy, hogy napjainkban még mindig magasabb, mint a 2000 -es évek elején volt. Ez azzal is járt, hogy a Mag 10 állástalanjai körében a fiatalok népességi arányukhoz képest többnyire és átlagosan is nagyobb mértékben felülreprezentáltak, mint a földrajzi és gazdasági értelemben egyaránt perifériásnak számító tagországokban. Ezt mutatja az Artner [2013a], [2013b] által kidolgozott ún. RIM (relatív ifjúsági munkanélküliségi ráta) is, ami a 15-24 és a 15-74 éves munkanélküliek arányát viszonyítja a 15-24 évesek 15-74 éves népességen belüli arányához. 2016-ban a ráta a Mag10 átlagában 1,6, a DÉNY7-ében 1,2, míg a KKE11-ében és az EU28-éban 1,4 volt.

Több oka is lehet a Mag10-re vonatkozó előbbi eredményeknek. A perifériákénál fejlettebb ellátórendszereken túl az egyik mindenképpen az odairányuló vándorlás, ami a fiatalabb korosztályokat erősebben érinti, s ami a küldő országokban csökkenti, a fogadókban pedig növeli a munkaerö-kínálatot. Ezt az Eurostat-adatok (Eurostat [2018f], [2018g]) alapján végzett számítások is alátámasztják (aggregálásra alkalmas adatok csak 2006-tól találhatók, ezért a következő megállapítások a 2006-2016-os periódusra vonatkoznak):

- A 15-39 éves korcsoportban a foglalkoztatottak összlétszáma 10 millióval csökkent az EU28-ban (melynek 80 százalékát a DÉNY7 adta), miközben a harmadik országokból érkezett foglalkoztatottak létszáma 1,6 millióval, a nem a saját uniós tagországukban dolgozóké pedig 1,7 millióval nött (az EU-n kívülröl érkezők száma tehát némiképpen mérséklödött).

- A Mag10-ben a 15-39 éves korcsoport foglalkoztatotti létszáma 571 ezerrel lett alacsonyabb, míg a harmadik országokból bevándorló dolgozóké közel kétmillióval, az EU más tagországaiból származóké pedig 1671 ezerrel emelkedett. Ez azzal járt, hogy a Mag10 ebben a 
korosztályában a harmadik országokból érkezett munkavállalók aránya 7,8-ről 11,6 százalékra változott, míg az EU más tagországaiból származóké ennél is dinamikusabban, 3,4-ről 6,5 százalékra.

- A 15-24 évesek körében az összfoglalkoztatás 3865 ezer fövel csökkent. Ezen belül a harmadik országokból érkezett munkavállalók létszáma 47 ezerrel lett kevesebb, a nem a saját uniós tagországukban dolgozóké viszont 116 ezerrel nött, ami azt jelenti, hogy arányuk a korcsoportos foglalkoztatásban 2,3-ről 3,4 százalékra emelkedett (2008 és 2010 között egy kis visszaeséssel), elérve 2016-ban a 617 ezret. Többségük (2013-ban 78,9 százalékuk) a Mag10-ben talált munkát (a többi évre hiányosak az országadatok).

- Ugyancsak a 15-24 éves korcsoportban 896 ezerrel csökkent a Mag10 natív (nem külföldi) foglalkoztatottjainak száma, miközben a külföldi (más tagországokból és harmadik országokból származó) fiatalok foglalkoztatása 203 ezerrel nőtt.

- A Mag10-ben a 25 évnél fiatalabb munkanélküliek száma 356 ezerrel lett kevesebb (2016-ben 2,1 milliót tett ki). Ha a teljes migránsnövekmény (2016-ig 203 ezer fö) helyett natív munkavállalókat alkalmaztak volna, az ifjúsági munkanélküliek száma 2016-ban ennyivel alacsonyabb lett volna, az ifjúsági munkanélküliségi ráta értéke pedig 14,3 helyett 12,9 százalékot, míg a RIM nem 1,6-et, hanem 1,5-et tett volna ki.

Az ifjúsági munkanélküliséggel függ össze a NEET-ek (neither in employment nor in education and training - nem dolgozó és nem is tanuló fiatalok) arányának növekedése. E jelenségre az EU-ban elöször az 1980-as évek Angliájában figyeltek fel (bár Latin-Amerikában már akkor sem volt újdonság), de a politika azóta sem tud vele mit kezdeni (Artner [2014]). Az Eurostat adatbázisában (Eurostat [2018h]) a 2004. évtől kezdve találhatók adatok a NEET-ekre vonatkozóan. Eszerint a nem tanuló és egyben inaktív személyek aránya a 15-29 éves korcsoportban 2016-ban 8 százalék volt, ami alig valamivel kisebb, mint a 2004-es 8,2 százalék. Ezen belül a dolgozni nem kívánók 4,7 százalékot tettek ki 2016-ban, ami bár némi mérséklődést mutat a 2004-2005-ben tapasztalt 5 százalékhoz képest, mégiscsak azt tükrözi, hogy az adott feltételek mellett a NEET-ek bő fele nem akar beilleszkedni a bérmunka világába. Körükben a nőkre vonatkozó százalékos érték magasabb a férfiakénál, ami többek között az anyai szerepvállalással függ össze.

A perifériás tagországokban a NEET-ek korcsoportos népességhez viszonyított aránya nagyobb a többi tagországéhoz képest; a legalacsonyabb rátákat a fejlett centrumországokban mérik. (Lásd a 4. ábrát.) 
4. ábra. A nem tanuló inaktív fiatalok aránya az EU28-ban a 15-29 évesek körében, 2016 Százalék

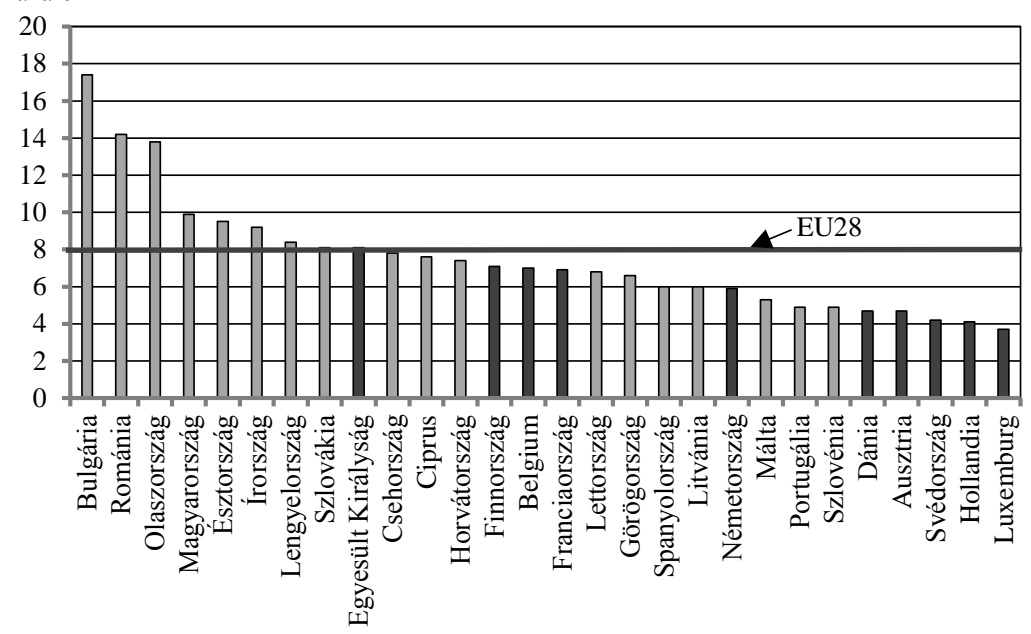

Megjegyzés. A sötétített oszlopok a Mag10-et jelölik. Itt és a továbbiakban Mag10: Ausztria, Belgium, Dánia, Egyesült Királyság, Finnország, Franciaország, Hollandia, Luxemburg, Németország, Svédország. Forrás: Eurostat [2018h].

\section{Atipikus foglalkoztatási formák}

Európában (a kontinens keleti felében éppúgy, mint a nyugatiban) a második világháború után kialakult társadalmi berendezkedés a korábbiaktól jelentősen eltérő, a munkavállalók milliói számára biztonságot és kiszámíthatóságot nyújtó foglalkoztatási formát tett általánossá: a határozatlan időre szóló alkalmazotti szerződés keretében először heti hat, majd később öt munkanapon keresztül végzett, napi nyolcórás alkalmazotti bérmunkát. Az 1970-es évekre ez a forma vált standarddá (tipikussá), az ettől eltérő foglalkoztatást pedig ,atipikusnak” kezdték nevezni, még ha az utóbbiak közül nem egy igen elterjedt is volt a második világháború elött (különösen a nök körében [például az otthon végzett vagy az idénymunka]). A jóléti államok 1980-as évekbeli fénykora óta a technológiai változások, a globálisan mozgó töke rugalmasság iránti igénye, valamint az európai integráció szabályainak egységesülése miatt egyre nő az atipikus foglalkoztatás szerepe, és új formák is járultak e foglalkoztatási kategóriához. Hangsúlyozni kell tehát, hogy ezekért a változásokért nem a 2008-as válság a felelös: az 1995 és 2008 között keletkezett új munkahelyek több mint fele részmunkaidös, határozott időtartamú szerzödésre épülö vagy önfoglalkoztatás volt (OECD [2017] 13. old.). 
Ma atipikusnak nevezünk minden foglalkoztatási formát, ami eltér az elözőkben leírt (teljes munkaidős, határozatlan időre szóló és alkalmazotti szerződésen alapuló) foglalkoztatástól. (Lásd még Hárs [2010], [2013].) Ilyenek mindenekelőtt a részmunkaidős, a határozott időre szóló, a megbízásos, az alkalmi, a távmunkában (otthon), az egyéni vállalkozásban, illetve a munkaerö-kölcsönzőn/ügynökségen (agency-n) keresztül történő, valamint a „,nullaórás” vagy opt-out klauzulát tartalmazó (a törvényes heti maximumnál több munkaórát is megengedő) szerződés által rögzített stb. foglalkoztatási formák. Szigorúan véve a teljes munkaidős, határozatlan idejü foglalkoztatás is idesorolható akkor, ha az - mint az napjainkban mindinkább szokás - speciális munkarendben történik (például munkavégzés terepen, 24/48 órás rendszerben vagy „rugalmas”, illetve csúsztatható munkaidőben stb.). Az atipikus foglalkoztatás terjedését az is elösegítettelelösegíti, hogy az információs technológiák fejlödése, a munkaügyi, vállalkozási szabályozások lazitása (a dereguláció), a megélhetési lehetöségek polarizálódása, az elbizonytalanodás és a jövedelemcsökkenés új üzleti megoldásokat szül(t). Idetartoznak például a közösségi/megosztásos gazdaság vállalkozásai, amelyek munkaerőpiaci hatásai gyakran negatívak (Major [2016], Osborne [2016]).

A tipikustól eltérő formák ma már olyan elterjedtek, hogy azt mondhatjuk: lassan az atipikus válik tipikussá - legalábbis az újonnan felvettek körében. Ezek egy része (inkább) kedvezö, más része viszont (inkább) kedvezőtlen, de mindenképpen csökkent biztonságot jelent a munkavállalók számára. A következőkben a különböző foglalkoztatási formák mérőszámainak alakulását mutatjuk be.

Kezdjük mindjárt az alkalmazotti formával, ami tipikus és atipikus foglalkoztatást is magában foglal. Az EU28-ban foglalkoztatott népességen belül az alkalmazottak aránya emelkedett, elérve 2016-ra a 85,2 százalékot. E növekedés azonban nem a fejlett országoknak (Mag10-nek) köszönhetö, ahol a mutató értéke bár az EU-n belül a legmagasabb, hosszú évek óta lényegében stagnál (2003 óta 88 százalék). A KKE11 átlagos alkalmazotti aránya nőtt a leggyorsabban, 2003 és 2016 között 77,5-röl 82,2 százalékra, amitől nem sokkal maradt le a DÉNY7 a maga rendre 76,2 és 79,8 százalékával.

Az alkalmazotti lét ugyan kiszámíthatóbb helyzetet jelent, mint más formák (például az önvállalkozói forma, lásd később), mégsem jár feltétlenül biztos, jól fizető állással. Egy, az Európai Parlament által készített jelentés (EP [2016]) szerint a határozatlan időre szóló és teljes (nyolcórás) munkaszerződések (tehát a tipikus alkalmazotti foglalkoztatás) aránya az EU-ban csökkent, 2014-ben már csak 59 százalék volt, és - ha egyelöre részesedésük még alacsony is, de - terjedőben vannak a rosszul fizetett, egyébként is bizonytalan, ,prekáriusnak” nevezhető munkahelyek: arányuk a foglalkoztatási formák összességén belül a 15-64 éves korosztályban 1,3-ről 2,3 százalékra nőtt 2000 és 2014 között, s 2016-ig ezen a szinten állt (Eurostat [2018i]). 
A prekariátus fogalmilag meglehetösen bizonytalan, nehezen körülhatárolható. Az ilyen jellegü léthelyzet több faktor eredője, a foglalkoztatás formáján túl múlik még a munka jellegén és egyéni helyzeteken (például a munkavállaló nemén) is (McKay et al. [2012]); az Eurostat maga sem adja meg pontos definícióját. Így aztán eltérő módszereket alkalmazva különböző eredményekre juthatunk. Ha például azt nézzük, hogy hányan vannak azok, akik még a minimálbért sem keresik meg, a prekárius foglalkoztatás aránya máris többszörösére nő. Például 2014-ben az Egyesült Királyságban - ahol az Eurostat fél százalék alatti prekariátust mért - a foglalkoztatottak közel 15 százaléka keresett kevesebbet, mint a minimálbér (EU [2016] 54. old.). Ök lehettek egyebek mellett gyakornokok, önfoglalkoztatók, önkéntesek, közmunkások, 16 éven aluliak (akik szabályszerüen is kereshetnek a minimálbér alatt) és persze idénymunkások vagy informális keretek között (azaz bejelentés nélkül) foglalkoztatottak. Megint más koncepció szerint az atipikus munkákat, elsősorban a határozott idejü szerződéseket és az ideiglenes (jellemzően a munkaközvetítőn keresztül történő) foglalkoztatást sorolják ide - ezeknél a bér azonos munkakör esetén is jelentősen alacsonyabb, mint a határozatlan idejü munkaszerződések esetében (da Silva-Turrini [2015]) -, valamint az önfoglalkoztatást és a nem önkéntes részmunkaidős állásokat (Letourneux [1998]).

A kutatók már a 2000-es évek elején megállapították, hogy bizonyos országokban, így föként Spanyolországban és Franciaországban, a prekariátus a munkaerőpiac strukturális jellemzőjévé vált (Duell [2004]). A 2008-ban kirobbant válság ugyan kedvezett az ilyen bizonytalan és rosszul fizetett foglalkoztatási formák terjedésének, annak hosszú távon mégis elsődleges oka a már jóval a válság előtt - az 1980-es évektől - meginduló munkaerőpiaci dereguláció volt, valamint a képzettségi különbségek a munkát keresők tudása és a piaci igények között.

A prekárius foglalkoztatás egy további formája a nullaórás szerződés, amikor a munkáltató nem vállal kötelezettséget a dolgozó munkával való ellátására és így a bérfizetésre sem. Alkalmi jelleggel, azonnal kell rendelkezésre állnia annak, aki így szerződik. E foglalkoztatási formát egyelöre az EU legtöbb tagországában tiltják, korlátozzák vagy nem alkalmazzák, azonban féltucat tagországban (Cipruson, Írországban, Finnországban, Máltán, Svédországban és az Egyesült Királyságban) mégis törvényesen elismert és kisebb-nagyobb mértékben elterjedt (KBS [2017]). A nullaórás szerződésekkel élenjár az Egyesült Királyság, ahol az így foglalkoztatottak száma 2000 és 2016 utolsó negyedéve között több mint négyszeresére, 905 ezer före, a foglalkoztattak 0,8 százalékáról 2,8 százalékára nőtt (ONS [2017]).

Bár az ügynökségeken keresztül ideiglenesen foglalkoztatottak (az ún. „temporary agency workers”) aránya az EU egészében nem éri el a 2 százalékot (2016-ban 1,7 százalék volt), és nem is nőtt 2006 óta (akkor 1,6 százalékot tett ki korábbi adatok azonban nincsenek) (Eurostat [2018j]), így is több mint 3,7 millió embert jelent, akik gyakran még a következő napi munkájukat sem látják elöre. Fize- 
tésük általában alacsonyabb, mint a közvetlenül a cégek által foglalkoztatott dolgozóké. Az Egyesült Királyságban számuk 2016-ban elérte a 865 ezret, fizetésük pedig átlagban 22 százalékkal maradt el a nem ügynökségi állandó foglalkoztatottakétól, de ha az ügynökségek alkalmazásában álltak (munkaerő-kölcsönzés), akkor már 45 százalékkal. A nullaórás szerződéssel és az ügynökségeken keresztül foglalkoztatottak halmaza részben átfedi egymást, 2016-ban az ügynökségi dolgozók 14 százaléka állt nullaórás szerződésben az Egyesült Királyságban. Még ha ezt figyelembe is vesszük, e két forma akkor is több mint 1,6 millió embert, a foglalkoztatottak több mint 5 százalékát érintette a szigetországban 2016-ban. Az ügynökségi munkások 40 százaléka migráns, akiknek nagyobb része az EU-ból, kisebb része harmadik országból érkezett az Egyesült Királyságba (Blitz [2016]).

Az Európai Parlament már idézett tanulmánya (EP [2016]) szerint a munka prekárius jellegü, illetve fokozott a veszély, hogy azzá válik, ha részmunkaidős (különösen, ha kényszer-részmunkaidős [amikor az illető szívesebben dolgozna több órában]), gyakornoki vagy informális (fekete), illetve azt ön- vagy határozott idejü foglalkoztatás keretében, munkaerö-kölcsönzön/ügynökségen keresztül, valamint nullaórás szerződés által szabályozva végzik. Mint látjuk, itt éppen azokról az esetekről van szó, amelyeket más néven atipikus foglalkoztatási formáknak nevezünk. Ezért a következőkben az ezeket jellemző trendeket vesszük sorra az Eurostat adatai alapján. Ha másképpen nincs jelölve, az adatok az EU28-ra, a 15-64 éves korosztályra és a 2002-től 2016-ig terjedő időszakra vonatkoznak.

1. Az atipikus foglalkoztatási formák között az egyik leggyakoribb a részmunkaidő. Bár ennek súlyát és jelentőségének változását tekintve a helyzet országonként/országcsoportonként jelentős eltéréseket mutat, az EU egészére nézve megállapítható, hogy 2013-ig nőtt, azóta viszont stagnál a részmunkaidőben alkalmazottak aránya az összes foglalkoztatott között. A részmunkaidősök száma 2016-ban meghaladta a 42 milliót, arányuk pedig megközelítette a 20 százalékot. Számszerüleg és arányaiban is a legtöbb részmunkaidöst a Mag10-t foglalkoztatta (2016-ban 31,8 millió fót, azaz 25,7 százalékot), a legkevesebbet pedig a KKE11 (2016-ban 2,7 millió főt, 6,2 százalékot). A DÉNY7 egészét tekintve a részmunkaidősök aránya 2002 és 2016 között megduplázódott, s 2016-ban 16 százalékot (8,1 millió főt) ért el. (Lásd az 5. ábrát.) E foglalkoztatási forma elsősorban a 15-24 éves fiatalokat érinti.

A részmunkaidős foglalkoztatás jelentőségének növekedése még jobban tetten érhető akkor, ha annak az utóbbi években keletkezett új állásokból való részesedését elemezzük. A vizsgált időszakban a foglalkoztatásnövekmény 68,8 százaléka volt a részmunkaidős állásoknak köszönhető az EU28-ban. A Mag10-ben a válság előtt (2002 és 2008 között) a foglalkoztatásnövekmény 61,8 százalékát, utána (2008 és 2016 között) már a 64,5 százalékát adta a részmunkaidős állások számának növekedése. A DÉNY7-ben még látványosabb volt a részmunkaidő terjedése, mert ott a foglalkoztatás 2008 után összességben csökkent, miközben a részmunkaidős állások 
száma nőtt. ${ }^{11} \mathrm{~A}$ KKE11-ben ezzel szemben a részmunkaidős állások száma és aránya is 2003 és a válságot követő két év (2009 és 2010) kivételével - jórészt a munkaerő Nyugatra vándorlásának köszönhetően - az időszak egészében csökkenő volt. (Lásd az 5. ábrát.)

5. ábra. A részmunkaidöben foglalkoztatott 15-64 évesek összes foglalkoztatotthoz viszonyított aránya az EU különbözö országcsoportjaiban, 2002-2016

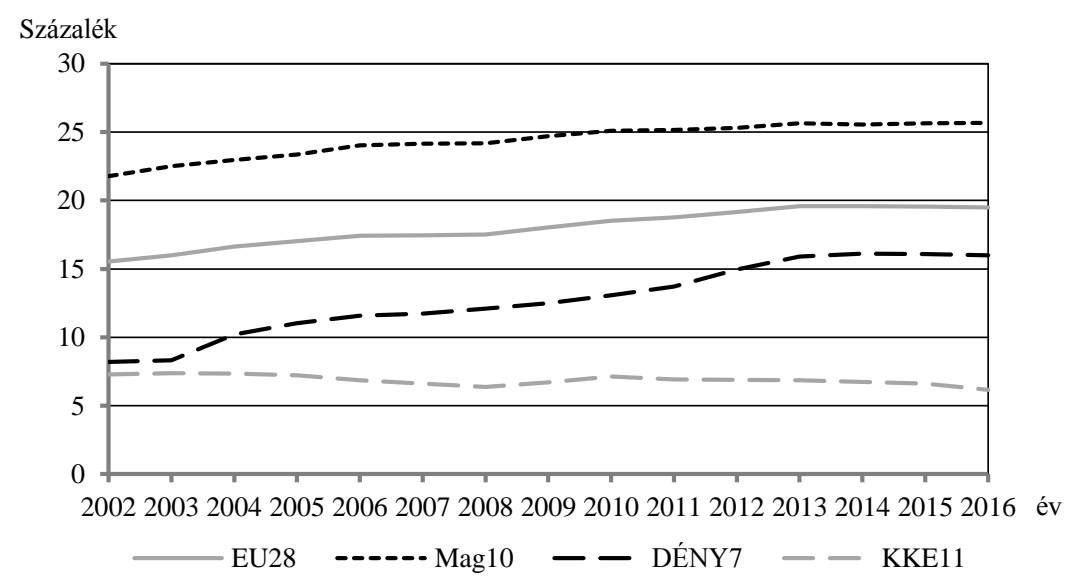

Megjegyzés. Itt és a továbbiakban DÉNY7: Ciprus, Görögország, Írország, Málta, Olaszország, Portugália, Spanyolország; KKE11: Bulgária, Csehország, Észtország, Horvátország, Lengyelország, Lettország, Litvánia, Magyarország, Románia, Szlovákia, Szlovénia.

Forrás: Saját számítás az Eurostat [2018k] alapján.

A részmunkaidőt csak kényszerüségből - teljes idejü állás híján - vállalók aránya emelkedik az összes részmunkaidős foglalkoztatotton belül (Eurostat 20181]): az EU28-ban 2002 és 2016 között több mint 10 százalékponttal 27,7 százalékra nőtt, ami elsősorban a válság sújtotta déli perifériákkal magyarázható. Mára a DÉNY7ben a részmunkaidősök közel kétharmada (!) kényszerből dolgozik ilyen formában, szemben a Mag10 jóval alacsonyabb, 18 százalék körüli értékével. A kettő között helyezkedik el a KKE11, ahol a kényszer-részmunkaidősök aránya 2008-ig csökkent, azóta pedig nő, és 2016-ban 33 százalékon állt, néhány százalékponttal elmaradva a 2002-es értéktől. (Lásd a 6. ábrát.)

A részmunkaidősök túlnyomó többsége (háromnegyede) nő, melyek körében alacsonyabb azoknak az aránya (2016-ban 24,6 százalék volt, szemben a férfiakra jellemző 37,6 százalékkal), akik nem jószántukból dolgoznak részmunkaidőben. Bár a részmunkaidőt nem önként vállaló személyek az EU28 összes foglalkoztatottján belül nem képviselnek jelentős arányt (csak körülbelül 5 százalékot), mégis

\footnotetext{
${ }^{11}$ Saját számítás az Eurostat [2018k] alapján.
} 
figyelemre méltó, hogy az elmúlt közel másfél évtizedben 6,4 millióval gyarapodott és napjainkban megközelíti a 12 milliót azoknak a száma, akik többet szeretnének dolgozni (és keresni), mint amire a munkaeröpiac jelenleg igényt tart, illetve lehetóséget nyújt.

6. ábra. A részmunkaidöt csak kényszerüségböl vállalók összes részmunkaidös foglalkoztatotthoz viszonyitott aránya az EU különbözö országcsoportjaiban, 2002-2003, 2007-2008 és 2015-2016 Százalék

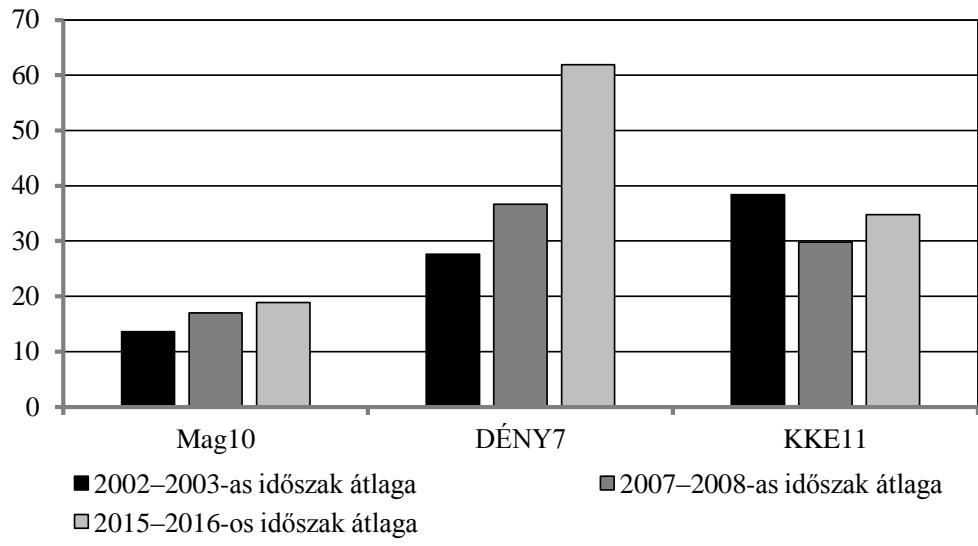

Forrás: Saját számítás az Eurostat [20181] alapján.

2. A másik jellegzetesen atipikus foglalkoztatási forma az ideiglenes alkalmazás. Ez magában foglalja a határozott idejü és az olyan szerződéseket, amelyek valamely esemény bekövetkezése (például egy feladat teljesítése, egy rendezvény bezárása) esetén szünnek meg. Bár az ilyen munkaszerződések elterjedtsége és időtartama országonként nagyon eltérö, mégis kimutatható az arányuk növekedése. Igaz, ennek mértéke nagy szórást mutat. Mindenesetre 2002 és 2007 között az EU egészében az ideiglenes szerződések száma és aránya is emelkedett, majd a válság hatására e növekedés megtorpant, és az arány valamelyest visszaesett, hiszen az így foglalkoztatottak elbocsátása a legkönnyebb. A csökkenés a DÉNY7 átlagában volt a legnagyobb mértékü, igaz, az ideiglenes foglalkoztatás az EU-n belül - Spanyolország és Portugália miatt - ebben az országcsoportban a legelterjedtebb. (Lásd a 7. ábrát.) A válság utáni években az ideiglenes szerződések aránya az EU egészét tekintve lényegében stagnált, 2013-ban azonban mindhárom országcsoportban (a KKE11-ben, a DÉNY7-ben és a Mag10-ben) ismét növekedni kezdett, így 2016-ban az EU28 átlaga már elérte a válság elötti szintet (12,1 százalék volt). A mutató 2016-ban csak öt országban (jelentősebb mértékben Spanyolországban, Lettországban és Litvániában, kisebb mértékben Bulgáriában és Finnországban) volt alacsonyabb, mint 2002-ben, az Egyesült Királyságban pedig csekély szinten lényegében változatlan maradt. A 
vizsgált időszakban az arány a leggyorsabban Lengyelországban, Horvátországban, Cipruson, Szlovákiában, Olaszországban, İrországban és Máltán nőtt, hasonló dinamikát a fejlett országok közül Hollandia, Luxemburg és Dánia mutatott. (Lásd a 7. ábrát.) Ennek megfelelően a KKE11-országcsoport átlaga a határozott időre szóló munkaszerződések arányát tekintve utolérte, majd 2013-tól le is hagyta a Mag10-ét, s 2015-2016-ban nagyjából az EU28 átlagának megfelelő 12 százalék körül alakult. Ennél magasabb, de hullámzó (2002 és 2016 között 13,6 és 16,6 százalék között) volt az ideiglenes foglalkoztatás aránya a DÉNY7 átlagában. (Lásd a 8. ábrát.)

7. ábra. Az ideiglenes foglalkoztatás aránya az EU28-ban, 2002, 2016

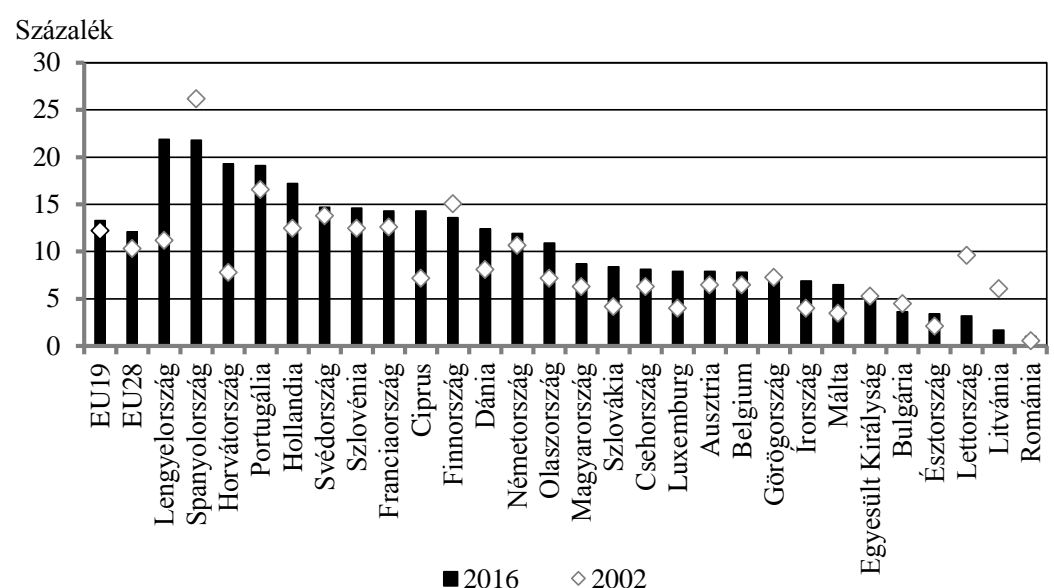

Forrás: Eurostat [2018b], [2018m].

8. ábra. Az ideiglenes foglalkoztatás aránya az EU különbözö országcsoportjaiban, 2002-2016 Százalék

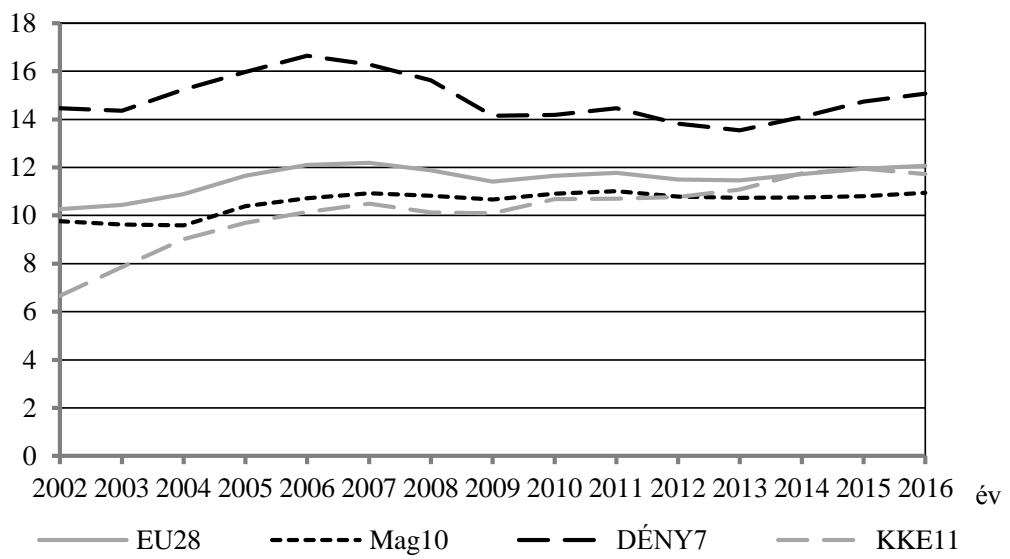

Forrás: Saját számítás az Eurostat [2018b], [2018m] alapján. 
Az ideiglenes foglalkoztatás korcsoportos vizsgálata megerősíti az elözőkben kirajzolódott trendeket. Az Eurofound nemrég publikált (2015-ös felmérésen alapuló) tanulmánya megállapítja, hogy inkább a 35 évnél fiatalabbak dolgoznak így, mintsem az idősek, de ez a foglalkoztatási forma a jelenleginél elterjedhettebbé válhat az idősebb korosztályok esetén is (Eurofound [2017b]). Az Eurostat EU28ra vonatkozó adatai szintén igazolják e feltételezést: 2002 és 2016 között az ideiglenes szerződéssel foglalkoztatottak aránya a 15-24 éves korcsoportban 32,6-ről 40,9 százalékra nőtt, a 25-54 éves korosztályban 7,8-ről 10,3 százalékra, az 55-64 évesek körében pedig 4,7-röl 5,3 százalékra. Ebböl az is kitünik, hogy a legdinamikusabban éppen a középső korosztályban emelkedik az ideiglenes szerződések aránya. Ezt a folyamatot szembetűnően mutatja az egyes korcsoportok részesedése is az ideiglenes foglalkoztatásban: a fiataloké (15-24 éveseké) 35,2-ről 28,5 százalékra csökkent, míg az idősebb korosztályoké értelemszerüen nőtt a vizsgált időszakban. Sőt, az Eurostat [2018g], [2018m] adataiból az is kiderül, hogy 2002 és 2016 között a 25-54 éves korcsoportban a foglalkoztatás növekményének 97,8 százaléka az ideiglenes foglalkoztatásból adódott! Az ideiglenes szerződések terjedése tehát valóban meghatározó trend, ami először a fiatalokat „érte utol" (mert belölük kerülnek ki legnagyobb számban az újonnan munkába állók), de néhány év alatt „lecsorog/lecsorgott” az idősebb korosztályokba is. Ez jelzi, hogy a folyamat tartós, tehát e foglalkoztatási formát később is egyre kevésbé váltja majd fel az annál nagyobb biztonságot nyújtó, határozatlan idejủ szerződés keretében végzett munka, illetve az idősebbek is mindinkább ideiglenes foglalkoztatási formákba szorulnak.

A munkaközvetitökön, munkaerö-kölcsönzökön keresztül megvalósuló ideiglenes, rövid (nemegyszer egy hónapnál rövidebb), alkalmi jellegü foglalkoztatás az ideiglenes foglalkoztatás egyik alcsoportját alkotja. Aránya az összes foglalkoztatáson belül viszonylag kicsi és meglehetősen stabil, az EU28 átlagában 2002 óta kis ingadozásokkal 1,7 százalék. Ennél jóval magasabb százalékos értéket mutat Szlovénia $(5,2 \%)$, Hollandia $(4,1 \%)$, Spanyolország $(3 \%)$ és alacsonyabbat Norvégia $(0,2 \%)$, illetve Magyarország (0,3\%) (Eurostat [2018j]).

3. A munkából való megélhetés fontos jelzöje a másodállások számának alakulása. Igen érdekes, hogy míg a vizsgált időszakban a másodállással rendelkező foglalkoztatottak száma a KKE11-ben több mint félmillióval csökkent, a DÉNY7ben lényegében változatlan maradt, a legfejlettebb EU-országokban, a Mag10-ben viszont (több mint 2,3 millióval emelkedett), ami így a csökkenést meghaladva az EU egészében is növekedést eredményezett. E téren kimagasló szerepe van Németországnak, ami a növekményböl 1,4 millió fővel részesedett. Ez nyilvánvalóan a 2000-es évek elején végrehajtott munkaerőpiaci reformoknak köszönhető, amelyek egyebek mellett az ún. „Geringfügig entlohnte Beschäftigte” (minimálisan fizetett foglalkoztatott), azaz a „mini jobs” rendszer bevezetésével serkentették a 
foglalkoztatást. A maximum havi 450 eurós fizetést jelentő, csökkentett társadalombiztosítási befizetésekkel járó „miniállásokban” ma már hét és fél millió ember dolgozik, köztük 2,7 milliónyian másodállásban (Bundesagentur für Arbeit Statistik [2018)], ami annak a jele, hogy kialakulóban van egy olyan munkavállalói réteg, amely egy állásból egyre kevésbé tud a maga választotta nívón megélni (White [2014]). 2002 és 2016 között jelentősen, 230 ezerrel nőtt a másodállások száma Hollandiában és több mint félmillióval Franciaországban (Eurostat [2018n]).

4. A munkaerőpiac egy speciális szegmensét adják az önfoglalkoztatók. Számuk csak mérsékelten emelkedett, s arányuk az összes foglalkoztatotton belül az EU28 átlagában lényegében nem változott (2016-ban 14 százalék volt). Ez a viszonylagos stagnálás azonban úgy állt elő, hogy az arány a Mag10-ben (2016-ban 11,5 százalékra) nőtt, a DÉNY7-ben és a KKE11-ben viszont, ahol egyébként jóval nagyobb mértékű az önfoglalkoztatás (például 2016-ban rendre 19,1 és 15,2 százalékos volt), 2002 óta csökkent (Eurostat [2018o]). Az Eurofound [2017a] legfrissebb felmérése szerint az európai önfoglalkoztatók túlnyomó többsége önként vállalta a megélhetésnek ezt a formáját, egyötödük számára azonban nem volt más alternatíva (az utóbbiak nagy része [például betegség esetén] anyagilag különösen bizonytalan helyzetben van). Az önfoglalkoztatók számára nem garantáltak sem a foglalkoztatotti jogok (például a ledolgozható munkaórák maximális száma vagy a minimálbér), sem a szociális biztonság (például megfelelő nyugdíj, táppénz), ami miatt ez a munkaforma egyértelműen a bizonytalan foglalkoztatási formák közé sorolható. Az önfoglalkoztatók sokrétü „táborát” az Eurofound öt csoportra osztja. A legjobb helyzetben azok vannak, akik maguk is foglalkoztatók, illetve azok, akiknek az anyagi helyzete stabil. E két csoport körülbelül azonos nagyságú, és együtt az önfoglalkoztatók közel felét adják (összesen 15,7 millió fö, az önfoglalkoztatók 49 százaléka). Az idetartozók, elsősorban a függetlenségük okán, viszonylagos anyagi biztonságban élnek, és elégedettek a helyzetükkel. A harmadik csoportot a „sebezhető" önfoglalkoztatottak (5,4 millió fö, 17 százalék), a negyediket a „rejtett” munkanélküliek (2,6 millió fö, 8 százalék) alkotják. E két, az önfoglalkoztatók egynegyedét kitevő kategóriát a pénzügyi biztonság hiánya és az anyagi függés jellemzi. Az ötödik csoport a kiskereskedőket és a mezőgazdasági kistermelőket foglalja magában ( 8 millió fö, 25 százalék), akiknek nagy része nehezen tartja fenn vállalkozását, sokat dolgozik, és egészsége, jóléte alacsony fokú. (A részletekért lásd Eurofound [2017a].) Egy másik tanulmány (Hatfield [2015]) alapján az önfoglalkoztatók átlagos jövedelme, ami amúgy is túlnyomórészt kisebb a foglalkoztatottakénak az átlagánál, Európa-szerte csökken mind abszolút értékben, mind a foglalkoztatottak jövedelméhoz képest, és ezért növekvő hányaduk igyekszik többet dolgozni vagy más munkát keresni. E munkaeröpiaci csoportra a közösségi politikákról szóló részben még visszatérünk. 
A munkakörülményekhez tartozik - akár tipikus, akár atipikus foglalkoztatási formáról van szó - a ledolgozott munka mennyisége, valamint a munkahely fizikai és mentális hatása. Ezekkel kapcsolatban a következők állapíthatók meg.

- Az EU28-ban általában csökkenő trendet mutat a foglalkoztatott népességen belül a (hivatalosan) 44 óránál többet dolgozók aránya, és a 2002-2016-os időszakban a fóllásban ledolgozott heti óraszám átlaga 38,2-ről 37,1-re csökkent. Ez az adat a teljes és a részmunkaidős állások együttes figyelembevételén alapul. Ha azonban a sokaságot szétbontjuk e két alcsoportra, azt találjuk, hogy a teljes idejü foglalkoztatásban a heti átlagóraszám csak alig (41,6-ről 41,4 órára) mérséklődött, a részmunkaidős állásokban viszont 19,9-röl 20,3-ra nőtt (Eurostat [2018p])! A teljes sokaságban a heti munkaidő jelentős (egy órát is meghaladó) mérséklődése abból adódik, hogy közben nagymértékben (15,5-ről 19,5 százalékra) nőtt az összes foglalkoztatotton belül a részmunkaidősök (tehát a nyolc óránál kevesebbet dolgozók) aránya. (Lásd az 5. ábrát.)

- Jelentősen, a vizsgált másfél évtizedben 18,4-ről 27,3 százalékra emelkedett a hétvégén is dolgozók ${ }^{12}$ aránya az EU28 foglalkoztatottjai között, amit valószínủleg elsősorban a szolgáltatások térnyerése, a szabadidő kommercializálódása, a fogyasztás felpörgése magyaráz. Ám a tagországi különbségek, részben a gazdaságok szerkezeti sajátosságai miatt, e téren is óriásiak. A turizmusra épülő, ráadásul válság sújtotta Görögországban a lakosság több mint 40 százaléka dolgozik hétvégén is, míg Magyarországon vagy Portugáliában csak alig több mint 10 százaléka (Eurostat [2018q]).

A globalizációt jellemző liberalizáció, dereguláció és privatizáció következtében korábbinál „rugalmasabbá” vált munkaerőpiacnak és a foglalkoztatás szerkezeti átalakulásának, illetve az információs technológiák terjedésének vannak a dolgozókra nézve pozitív hatásai (például a rugalmas munkavégzés hozzásegíti őket a munkájuk és a magánéletük közötti egyensúly javításához), alapjában véve azonban fokozott stresszt jelentenek és növekvő munkaintenzitást követelnek többségüktöl. Ennek egyik jele, hogy 2007 és 2013 között 25,1-ről 28,0 százalékra nőtt az EU28ban a foglalkoztatott személyek körében azoknak az aránya, akik a foglalkozásukkal kapcsolatban olyan rizikófaktorokról számoltak be, melyek mentális károsodást okozhatnak. E faktorokon belül több mint 80 százalékban a határidők szorítása és a túlmunka volt a meghatározó. Egyes fejlett országokban (például Franciaországban,

${ }^{12} \mathrm{Az}$ egy hónapban legalább két hétvégi napon dolgozókról van szó. 
Luxemburgban, Ausztriában és Svédországban) a dolgozók a mentális terhelésre panaszkodtak a legnagyobb arányban. A képzettebb munkavállalók esetén magasabbak voltak ezek az értékek (2013-ban egyharmad), mint az alacsonyabb végzettségüek között, csakúgy, mint a nagyobb vállalatok dolgozóinál a kisebb cégek alkalmazottaihoz képest (Eurostat [2018r]).

Talán meglepően hangzik a XXI. században, de még ennél is jelentősebbek és gyorsabban növekednek a dolgozókra leselkedő fizikai veszélyek a munkahelyeken (Eurostat [2018t]). Legalábbis a megkérdezett dolgozók szerint, akiknek 2007-ben (amikor az első ilyen felmérés készült [a módszertanról lásd Eurostat [2018s]]) még „csak” 37,7 százaléka nézett szembe munkahelyén fizikai egészségre káros veszélytényezőkkel, de 2013-ban már 50,9 százalékuk. Csökkenést csak három országban mértek (Máltán, Dániában és az Egyesült Királyságban). 2013-ban a legnagyobb arányban (75 százaléknál többen) Franciaországban, Észtországban és Portugáliában, a legkevésbé (30 százaléknál kevesebben) Máltán, Norvégiában, illetve Dániában vélték úgy a dolgozók, hogy fizikai egészségük veszélyben van. A vállalatok mérete alapján nem voltak nagy különbségek a válaszarányokban. A legfontosabb veszélyeztető tényezők között a nehezen fenntartható testtartás és mozdulatok mellett a nagy erőfeszítést igénylő vizuális koncentráció járt az élen, ami nyilvánvalóan a számítógép elött végzett munka következménye.

\section{Szegénység a munkaerőpiacon}

A dolgozó szegények azok, akik munkavégzés mellett is kevesebb jövedelemmel bírnak (beleértve a szociális transzfereket is), mint az adott ország mediánjövedelmének 60 százaléka - vagyis szegénynek számítanak ott, ahol élnek, függetlenül attól, hogy más, alacsonyabb bérü országok átlagos munkásaihoz képest mennyi a jövedelmük. Arányuk az EU összes foglalkoztatottja körében 8,1-röl 9,6 százalékra nőtt a 2005-2016-os időszakban (Eurostat 2018u]). Csak hat országban találkozhatunk egyértelmű csökkenéssel, a többiben emelkedett vagy lényegében stagnált e mutató.

2006 és 2014 között (amely évekre van adatunk) növekedést mutatott, és még a dolgozó szegényekénél is magasabb volt az EU28 átlagában az alacsony keresetüek aránya. Ez azért más kategória, mint az elóző, mert a teljes jövedelem helyett a munka egységárát veszi alapul. Alacsony keresetűnek számítanak azok, akiknek órabére kevesebb mint a nemzeti órabér mediánjának kétharmada. E foglalkoztatotti kategória arányát illetően csökkenés a keleti és a déli periféria országaiban volt tapasztalható (a KKE11 nyolc országában és a DÉNY7 két országában), míg Belgium, Luxemburg és az Egyesült Királyság kivételével a fejlett Mag10-ben mindenütt nagyobb 
lett az alacsony keresetúek aránya. Bár a mutató értéke az EU28 átlagában elsősorban a férfiak körében emelkedett: 2014-ben mégis a férfiak 17,2 százaléka, a nőknek viszont 21,2 százaléka tartozott ebbe a kategóriába.

Munkaeröpiaci bizonytalanságok és anyagi gondok miatt 2000 óta a legtöbb EUtagországban nagyobb lett a jövedelmi szegénység kockázatának kitettek aránya. Csoportjuk 2005-ben az EU28 lakosságának 16,5, 2016-ban pedig már a 17,3 százalékát tette ki. A gyermekek és a fiatal felnőttek körében még ennél is magasabb e mutató értéke: a 18-24 éves korosztályban a 2005. évi 19,5-ről 2016-ra 23,4 százalékra emelkedett. Növekedett a mediánjövedelem 40 és 50 százaléka alatt élők aránya is (2016-ban rendre 6,4 és 10,9 százalékra), ami elsősorban a fiatalokat érinti (Eurostat [2018v]).

Az EU számon tartja azokat is, akik egyéb okokból vannak hátrányos helyzetben, például súlyos anyagi deprivációtól szenvednek (kilenc fogyasztási tétel közül legalább négyről lemondani kényszerülnek ${ }^{13}$ ) vagy nagyon alacsony munkaintenzitású háztartásban élnek. Ezek a csoportok az imént tárgyalt jövedelmi szegényekkel együtt teszik ki az ún. szegénységgel vagy társadalmi kirekesztődéssel fenyegetettek csoportját. A 2010 júniusában elfogadott Európa 2020 stratégia (Eurostat [2018x]) szerint az EU 2020-ra 20 millió főt kíván kiemelni ebből a kategóriából 2008-hoz képest, amikor 117,230 millió ember, a lakosság 24 százaléka tartozott ide. A válság következtében a szegénységgel és a kirekesztődéssel fenyegetettek tábora azonban nemhogy csökkent volna, de egyre gyarapodott, és 2012-ben 123,6 millióval tetőzött (az EU28 összlakosságának 24,7 százaléka). Azóta számuk örvendetesen csökken(t), de 2016-ban még mindig 118,036 milliót tett ki, 806 ezerrel többet, mint 2008-ban (Eurostat [2018z]).

A szegénység és a társadalmi polarizálódás összefügg. Az OECD [2017] megállapítja, hogy a jövedelmi és a vagyoni egyenlötlenségek különböző mértékei léteznek Európában, de a meghatározó trend az elmúlt három évtizedben a növekedés. Míg régebben többnyire öregeket, ma inkább fiatalokat és gyermekes családokat találunk a legsérülékenyebb társadalmi csoportok között. A válság idején az egyenlőtlenségek megugrottak, majd az azt követő években a legtöbb országban stabilizálódtak vagy tovább növekedtek, és ennél csak azért nem nagyobb mértékben, mert a kormányok adópolitikával és állami szociális juttatásokkal igyekeztek a helyzeten javítani. A jövedelmi egyenlötlenségek növekedése a munkaeröpiacon bekövetkezett változásokkal, elsősorban a keresetekben és a munkafeltételekben mutatkozó különbségekkel magyarázható. Nemcsak arról van szó, hogy jelenleg még mindig hiányzik több millió munkahely a válság előtti évekhez képest, hanem arról is, hogy az új munkák növekvő része rosszul fizetett és bizonytalan.

\footnotetext{
${ }^{13}$ Vagyis, akiknek a következők közül legalább négy nem áll módjában: 1 . időben fizetni a rezsit; 2. megfelelően füteni a lakást; 3. váratlan kiadásokat fedezni; 4. legalább kétnaponta húst enni; 5 . évente legalább egy hetet üdülni; 6 . autót, 7 . mosógépet, 8 . tévét vagy 9 . telefont birtokolni.
} 


\section{A munkaerőpiacot érintő közösségi politikák áttekintése}

Az EU (akkori nevén EGK) 1957-es megalakulásakor és még utána is jó ideig nem alkotott közös politikát a munkaeröpiaccal kapcsolatban. Erre az 1950-es és az 1960-as években nem is volt szükség, mert a gazdaság a megújulás és a fellendülés szakaszát élte, a foglalkoztatás kvázi teljes volt mindössze 2-3 százalékos strukturális, illetve frikciós munkanélküliséggel (nemcsak Európában, de az Egyesült Államokban és Japánban is). Már akkor is kivételt képeztek a déli perifériák, így az alapító tag Olaszország, amely 1957-ben a hattagú Közösség munkanélküliségének közel kétharmadát adta (EC [2007] 10. old.). Ezzel együtt is az EGK munkaerőpiacát az első évtizedben rohamosan növekvő bérek és javuló életminőség jellemezte, amit a kelet-közép-európai „szocialista” példa demonstrációs hatása által is ösztönzött jóléti újraelosztó rendszerek kiépülése segített.

A kezdetekben mindössze a Közösség alapításával egyidejüleg létrehozott ESzA (Európai Szociális Alap) foglalkozott a munkaerőpiaccal, elsősorban a mobilitást, a képzést és az átképzést segítve. Akkoriban az alap az EU teljes közösségi költségvetésének mindössze 1 százalékát tette ki. Változást az 1970-es évek válsága hozott, amikor, leginkább a második olajárrobbanás után, kiderült, hogy korszakos váltás következett be, s a munkanélküliség tartósan magas szinten stabilizálódik. Az ESzAnak tehát bővülnie kellett.

Az első reformra ugyan már 1971-ben sor került (növelték az alap költségvetését), de jelentős változásokat csak a későbbi évek hoztak. Az Egyesült Királyság, Írország és Dánia 1973-as csatlakozása nyomán, 1975-ben létrejött az ERFA (Európai Regionális Fejlesztési Alap). Ennek feladata az elmaradott területek infrastrukturális fejlesztése lett, kiegészítendő az ESzA munkaerőpiacra irányuló tevékenységét. A két alapot együtt „strukturális alapoknak” nevezték.

Az 1970-es években megugró munkanélküliséggel együtt jelentkezett az ifjúsági munkanélküliség problémája is, így az ESzA ekkor fordított először külön figyelmet a fiatalokra. Ekkortájt kezdte fókuszcsoportként kezelni a nőket is, mivel azok munkaerőpiaci integrációja a gazdasági szerkezetváltás következtében fontos gazdasági kérdéssé vált. A főként férfiakat foglalkoztató nehézipari struktúrák ugyanis lebomlottak, és fokozott igény jelentkezett a nők foglalkoztatására a szolgáltatási, illetve az automatizált területeken. Alapításának ötvenedik évfordulóján az alap egyik sikersztorijának könyvelték el, hogy míg az 1970-es években a foglalkoztatottaknak csak alig egyharmada volt nő, addig a 2000-es évekre már közel fele (EC [2007] 3. old.). Ezt a fejlődést persze erős túlzás az alap tevékenységének tulajdonítani, hiszen hasonló folyamat játszódott le az Egyesült Államokban, sőt KeletEurópában is. Az ESzA ugyanakkor fokozott figyelmet fordított a fogyatékosok és az 50 év felettiek munkaerőpiaci részvételének elősegítésére is, és ugyancsak megnyitotta forrásait a vállalatok, illetve a civil szervezetek számára. 
Felhasználásában az 1980-as évek végétől még nagyobb súlyt helyeztek a képzésre, valamint a leszakadó régiókban élők megsegítésére, így a források nagyobbik fele Görögországba, Írországba, Mezzogiornoba (Olaszország), Észak-Írországba, Andalúziába (Spanyolország), Portugáliába stb. áramlott ( $E C$ [2007] 23. old.). Amikor 1988-ban a Közösség úgy döntött, hogy az éves költségvetésről áttér a hosszabb távú kiszámíthatóságot biztosító középtávú pénzügyi tervezésre, az ESzA is megújult: megnövelték és több évre előre biztosították forrásait, amelyek így könnyebben beilleszthetők lettek a nemzeti tervekbe; emellett a korábbiaknál hosszabb távú stratégiákat lehetett felvázolni a leginkább rászoruló régiók, valamint társadalmi csoportok felzárkóztatására. Ezzel az is lehetôvé vált - amire a 2008. évi válság után nagyon is szükség volt -, hogy a későbbi évekről ,elörehozzanak” összegeket. A reformokat követően (az 1990-es években) az alap a becslések szerint évente több mint 2 millió ember szakmai képzését vagy elhelyezkedését segítette ( $E C$ [2007] 26. old.).

Az 1980-as években a déli kibővüléssel (Görögország, Spanyolország, Portugália csatlakozásával) olyan elmaradott területek váltak az EU részévé, amelyek felzárkóztatására külön gondot kellett fordítani. Ugyanakkor a globalizációval járó technológiai és intézményi változások is éreztették hatásukat a munkaerőpiacon. Minderre válaszul a strukturális alapokat az EU újonnan megalkotott kohéziós politikájának részévé tették. 1994-ben alakult meg (többek között az akkor várható „,keleti kibővülésre" való tekintettel) a Kohéziós Alap, így attól kezdve a kohéziós politika már három alapra (az ERFA-ra, az ESzA-ra és a Kohéziós Alapra) támaszkodhatott, és az 1994-99-es programperiódusban dupla akkora forrásból gazdálkodhatott, mint elötte. Az EU 1994-ben megalkotta foglalkoztatási stratégiáját, az 1997-ben hatályba lépett Amszterdami Szerződéssel pedig közösségi szintre emelte a foglalkoztatáspolitikát. 1998-tól kezdve a tagországok közös iránymutatásokat dolgoztak/dolgoznak ki, és ehhez igazították/igazítják saját foglalkoztatáspolitikájukat. Az iránymutatásokat háromévente újítják meg, és 2004 óta a gazdaságpolitikai irányvonalakkal (az ún. integrált iránymutatásokkal) is összehangolják azokat.

Az ESzA keretében az 1990-es években három új közösségi program született: a szakképzés és a foglalkoztatás elősegítésére az EUROFORM, a fogyatékkal élők képzésére a HORIZON és a nők munkaerőpiaci részvételének támogatására a NOW (New Opportunities for Women - A Nők Új Lehetőségei). Ezeket később további programok sora követte, köztük az ifjúságra koncentráló YouthStart (EC [2007] 31-32. old.).

A munkanélküliség s vele a munkaerőpiaci differenciálódás, valamint az alsó rétegek leszakadása azonban mindezek ellenére sem enyhült. Az EU15 átlagában a gazdaságilag aktív népességhez viszonyított munkanélküliség az 1980-as évek közepére 9 százalék fölé emelkedett, és 1994-ben már meghaladta a 10 százalékot. Az információtechnológiai fellendülésnek köszönhetően 1994 és 2001 között 4,7 millió fővel csökkent az álláskeresők száma, ám azután a javulás megtorpant. A munkanélküliségi ráta még 2007-ben, a válság elött is több volt, mint 7 százalék (EC [2018a]). 
A munkanélküliek seregét részben a legkisebb, legsérülékenyebb vállalkozások, az önfoglalkoztatók rétege „táplálta”. Az önfoglalkoztatók száma (és a népességhez viszonyított aránya) az 1960-as évekig Nyugat- és Dél-Európában (az EU15-ben) magas volt, de a termelés felfutása - a vállalatok munkaerőigényének növekedése -, majd az 1970-es évek válsága következtében csökkent: az önfoglalkoztatók nagy része így előbb foglalkoztatottá, később munkanélkülivé vált. E folyamatok hatására a népességhez viszonyított arányuk is évről évre jelentősen esett az 1960-as évek elejétől az 1970-es évek végéig, miután egy évtizednyi stagnálást követően az 1990 utáni első években ismét egy rövid ideig csökkent. Azóta az EU15 átlagos mutatója lényegében változatlan (körülbelül a népesség 9 százaléka). Nem úgy a munkanélküliség, ami 1973 óta hullámokban növekszik. Az önfoglalkoztatók és a munkanélküliek együttes aránya a 15-74 éves népességben 1974-től a konjunktúra hullámzásaival párhuzamosan mozog, de hosszú távon növekvő trendet mutat. 2016-ban az EU15 átlagában 14,6 százalékot tett ki, vagyis minden hetedik ember élt meglehetősen bizonytalan léthelyzetben. Az EU28-ra 2002-től vannak adatok, melyek hasonló trendet mutatnak, bár ez esetben az arány valamelyest kisebb, 2016-ban 14,1 százalék volt. (Lásd a 9. ábrát.)

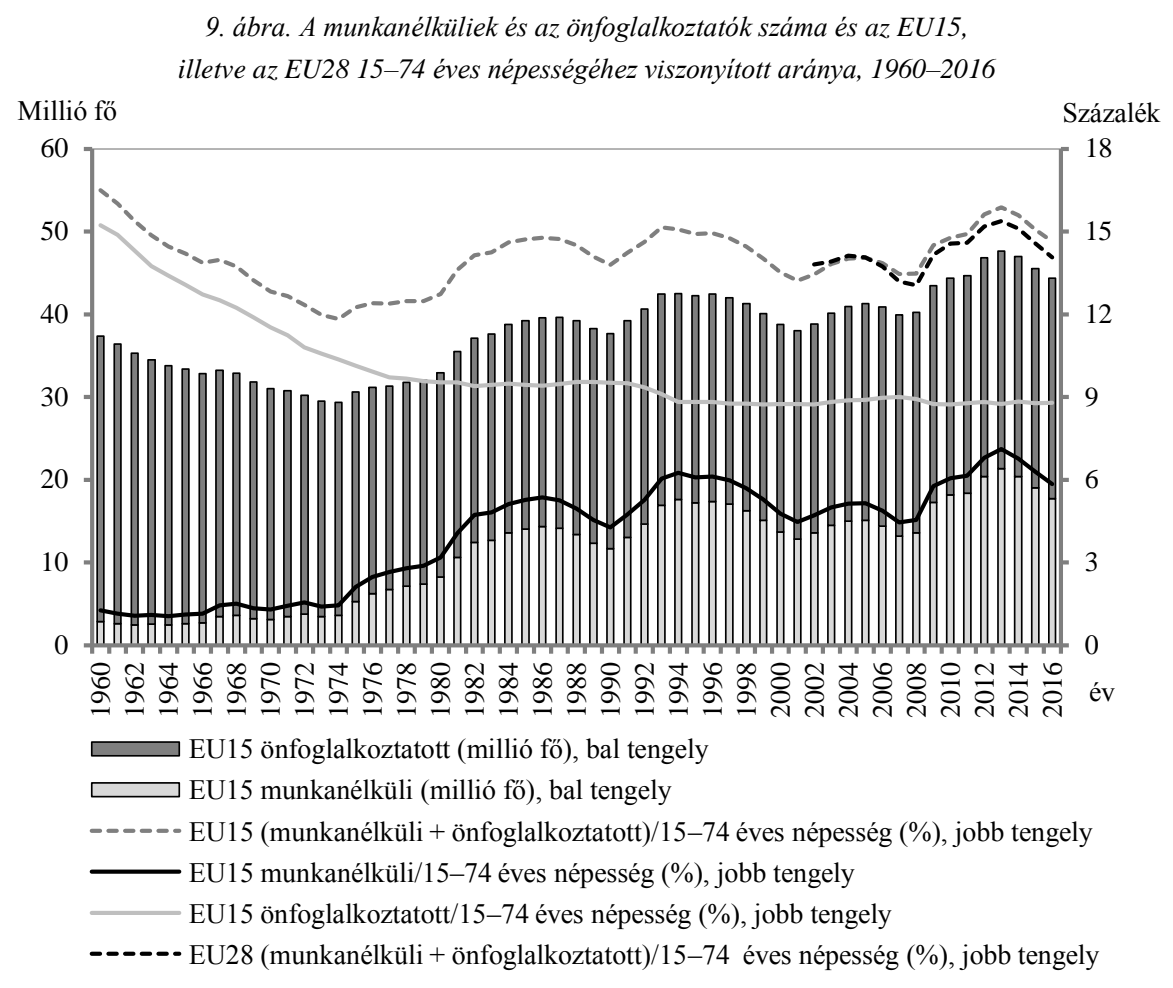

Forrás: Saját szerkesztés az EC [2018a] alapján. 
A foglalkoztatási ráta és a versenyképesség növelésének vágyával hirdették meg 2000-ben a Lisszaboni Stratégiát, amely szerint az EU-nak 2010-re a világ legdinamikusabb és legversenyképesebb tudásintenzív régiójává kellett volna válnia, és egyebek mellett 70 százalékos foglalkoztatási rátát produkálnia a 15-64 éves lakosság körében, (60 százalékot a nők, 50 százalékot az 55-64 évesek esetén). Ezzel együtt az egész életen át tartó tanulás, az aktív munkaerőpiaci politikák ${ }^{14}$, a vállalkozókedv (önfoglalkoztatás) bátorítása, a kis- és közepes méretủ vállalatok támogatása, illetve az esélyegyenlőség előrébb került az ESzA prioritásainak sorában. A 2000-es években az EU kibővülésével járó migráció nyomán a társadalmi integráció, a menekültek segítése, valamint a társadalom elöregedésének elörehaladtával az aktív időskor népszerüsítése is felzárkózott a topprioritások közé.

Mint az az előbbi elemzésünkből kiderült, a Lisszaboni Stratégia nem bizonyult sikeresnek. Ráadásul a 2008-as válság újabb csapást mért az EU munkaerőpiacára, s a megugró munkanélküliséggel együtt növelte a jövedelmi, a társadalmi és a területi egyenlőtlenségeket is. A 2010-ben megalkotott új stratégia, az Európa 2020 már figyelembe veszi az oktatásban töltött idő kitolódását, és a foglalkoztatási rátát a 20-64 éves korosztályra határozza meg (cél a 75 százalék), ugyanakkor a következőket kívánja elérni: a korai iskolaelhagyók arányának 10 százalék alá szorítása, a felsőfokú végzettséggel rendelkezők arányának legalább 40 százalékra emelése a 30-34 évesek körében, illetve a szegénységgel és a kirekesztettséggel fenyegetettek számának 20 millió fővel való csökkentése 2008-hoz képest.

2016-os adatok szerint a második és a harmadik célkitüzés már közel áll a megvalósuláshoz: az EU28 átlagában a korai iskolaelhagyók aránya a 2008-as 14,7-ről 10,7 százalékra esett vissza, a 30-34 évesek körében pedig a korábbi 31,1 helyett már 39,1 százalékot tesznek ki a felsőfokú végzettséggel rendelkezők. A 20-64 évesek foglalkoztatási rátája viszont alig növekszik: míg 2008-ban 70,3, 2016-ban is még csak 71,1 százalék volt. A legrosszabbul azonban a szegénységgel és a kirekesztettséggel fenyegetettek helyzete áll. Mint korábban kimutattuk, itt nemhogy nem következett be 20 milliós csökkenés, de az ilyen helyzetben levő személyek száma 2016-ban közel 1,7 millióval több volt 2008-hoz képest (Eurostat [2018x]).

Gazdaságpolitikai célok mellett a már említett szociális célokat is szolgálja a 2014-2020-as pénzügyi keret. Az ESzA ebben a programperiódusban a fenntartható és a minőségi foglalkoztatást, a munkaerő mobilitását, a szegénység elleni harcot, a társadalmi integrációt, a szakképzést és az egész életen át tartó tanulást, valamint a közigazgatás hatékonyságának növelését igyekszik segíteni (EU [2013]).

${ }^{14}$ A passzív munkaerőpiaci politikák (például a munkanélküli-ellátás) nem változtatják meg a munkaerōpiac állapotát, hanem a munkanélküliség következményeit segítik elviselni. Ezzel szemben az aktív munkaerőpiaci politikák célja, hogy a munkaerőpiac állapotát alakítsák, vagyis munkába segítsék az embereket. Példaként említhető erre a képzés, a vállalkozóvá válás segítése vagy a munkáltatóknak nyújtott járulékkedvezmények. 
A fiatalokat érintő kezdeményezés a „Youth on the Move” (Mozgásban az Ifjúság), az EU egyik zászlóshajóprogramja, ami a képzés, a szakképzés és az oktatás fejlesztésén, illetve a mobilitás támogatásán túlmenően a munkaerőpiaci elhelyezkedés elösegítésére is koncentrál. A „Youth Guarantee” (Ifjúsági Garancia) Program keretében 8 milliárd eurót szánnak arra, hogy a 25 százalékosnál nagyobb ifjúsági munkanélküliségi rátával küzdö területeken élö, 25 év alatti munkanélküli fiatalokat képzéssel, vállalkozási formában vagy egyéb módon, nem több mint négy hónapon belül pénzkeresethez juttassák azt követően, hogy kikerülnek az iskolából, ( $E U$ [2010]).

Az EU aktív munkaerópiaci politikáját elsősorban segíteni hivatott ESzA teljesítményét, illetve általában az EU szociális politikáját annak tükrében is érdemes megítélni, hogy minderre mekkora összeget szántak/szánnak a tagországok.

Kezdetekben az ESzA költségvetése a teljes közösségi költségvetés csupán 1 százalékát tette ki, s bár a 2000-es évekre részesedése 10 százalékra „kúszott fel” ( $E C$ [2007] 3. old.), még ez is csekély összeg, ha figyelembe vesszük, hogy az EU költségvetése a tagországok összesített GDP-jének mindössze 1 százalékával ér fel. Ráadásul az ERFA az elmúlt két és fél évtizedben egyre nagyobb részét kapta a kohéziós politikára szánt forrásoknak, amely kedvezőtlen folyamatnak csak a 2014-2020-as keretprogram vetett véget, amikor az ESzA részesedését 23,1 százalékban minimálták, s döntöttek arról is, hogy ennek érdekében a nemzeti hozzájárulásoknak is legalább 20 százalékban az ESzA-ba kell befolyniuk. 2014 és 2020 között az ESzA a strukturális alapok 24,8 százalékát (a teljes uniós költségvetés 9 százalékát) kapja. Így összesen 121,1 milliárd euróból gazdálkodhat, amiből 84 milliárd az EU költségvetéséből érkezik (a többit a tagországok adják hozzá). Ez 9 milliárddal több, mint a korábbi programperiódusban volt, ami ahhoz képest különösen szép eredmény, hogy az EU teljes költségvetési kerete és a kohéziós politika „büdzséje” is 2007-2013-hoz képest mintegy 4 százalékkal zsugorodott (EC [2018b]).

Az eddigi eredmények azt mutatják, hogy az EU foglalkoztatáspolitikája és szociális intézkedései is elégtelenek a sokat hangoztatott „Európai Szociális Modell” megvalósításához. Ahogy azt de la Porte és Jacobsson [2012] kimutatta, a munkaerőpiaci feltételrendszerek alakítása továbbra is elsősorban tagországi kézben van, és mind nemzeti, mind uniós szinten gazdasági és pénzügyi prioritásoknak alárendelt. A teljes foglalkoztatásra törekvés megragad a politikai szlogenek szintjén, a valóságos folyamatok a munka további piacosítása felé mutatnak az emberi erőforrások szisztematikus fejlesztése helyett.

De la Porte és Heins [2015] pedig már kifejezetten a válság, illetve az azt követö nemzeti és uniós politikák hatását vizsgálva arra a következtetésre jutott, hogy a költségvetési fegyelem érdekében 2010 óta bevezetett uniós eszközök és politikák jelentősen szükítik a tagországok szociálpolitikai mozgásterét, még az egészséges gazdasággal rendelkező országokban is. A tagországok költségvetése, benne a szoci- 
ális kiadások, mára úgy a tervezés, mint a megvalósítás fázisában az EU felügyelete alatt áll. Az Európa 2020 foglalkoztatás- és szociálpolitikai eszközei gyengék a költségvetési fegyelmet védő intézményekhez képest.

Az előbbi megállapításokat és a cikkünk korábbi fejezeteiben ismertetett negatív tendenciákat az uniós állampolgárok véleménye is tükrözi. Az Eurobarométer felmérése szerint több mint 80 százalékuk a munkanélküliséget, a szociális egyenlötlenségeket és a migrációt tekinti a három legfőbb európai kihívásnak, és erős szociális hálót szeretne látni. Tíz polgárból hét elégedetlen az európai (nemzeti és közösségi) foglalkoztatás- és szociálpolitikával, továbbá az emberek több mint fele véli úgy, hogy nem egyenlők az esélyek mindenki számára, és a jövő generációinak élete nehezebb lesz, mint a mostanié (EC [2017a] 20. old.).

A 2017 novemberében, Göteborgban elfogadott szociális jogok európai pillérének megvalósításához a deklarációk nem elégségesek; ahhoz tagországi akarat és jóval nagyobb ESzA-költségvetés (ehhez pedig növekvő adóbevétel) kell, amit nem lesz könnyü „összehozni”. Ugyanis, ami kedvezőtlen a munkavállalóknak, és alacsonyan tartja az egységnyi munkaerőköltséget, az kedvező a profitorientált munkaadóknak. Az európai nagyvállalatokat képviselő Business Europe elnöke, Emma Marcegaglia a 2017. októberi 18-ai tripartit - vagyis a munkáltatók és a munkavállalók európai szintủ képviselöit, illetve a legfőbb EU-intézmények vezetőit összehozó - Európai Szociális Csúcstalálkozón tartott beszédében kijelentette, hogy nem támogatja egy jelenlegin túlmenő, közös európai szociális standard bevezetését (Marcegaglia [2017]), ami jelzi, hogy a tőkének alapvető érdeke füződik a munkaeröpiaci különbségek fenntartásához.

\section{6. Összegzés}

Annak ellenére, hogy Európát soha nem látott gazdasági és technológiai fejlettség jellemzi, munkaerőpiacán több tekintetben kedvezötlen jelenségeknek lehetünk tanúi. Bár a helyzet tagországonként változó és hullámzó irányt mutat, európai szinten bizonyos meghatározó tendenciák jól kirajzolódnak.

Az EGK-ban az 1970-es évek után nagyobb lett a munkanélküliség és az ifjúsági munkanélküliség, az ezredforduló utáni, kibővült EU-ban pedig kisebb-nagyobb mértékben, de egyértelmủen nőtt a munkában töltött évek száma és az időskori foglalkoztatás, a részmunkaidőben (és a nem önként részmunkaidőben), az ideiglenesen (határozott munkaidővel), illetve egyéb prekárius formában alkalmazottak, a dolgozó szegények és az alacsony keresetüek, valamint a jövedelmi szegénység és a kirekesztődés kockázatának kitettek aránya. A jövedelmi egyenlőtlenséget jelző Gini-index, 
akár a szociális juttatások előtti, akár az azok utáni helyzetből számolják, szintén emelkedő trendet mutat, amit elsősorban a keresetekben és a munkafeltételekben mutatkozó munkaerőpiaci különbségek okoznak. Megállíthatatlanul terjednek az atipikus foglalkoztatási formák, amelyek az új kor technológiájának köszönhető rugalmasság révén több tekintetben megkönnyíthetik a dolgozók helyzetét, de egyéb jelenségekkel - úgymint a szabadpiaci viszonyokkal és a migrációval - ötvözve egyben utat nyitnak a prekárius bérmunkák felé. Ezek elsősorban azokat érintik, akik újonnan vagy újra a munkaerőpiacra lépnek, így különösen a fiatalokat, a nőket és a migráns munkavállalókat.

Ugyan a közösségi politikák, elsősorban az ESzA köré szerveződve, mindig igyekeztek igazodni az adott helyzethez, és ott segíteni, ahol a legjobban szükséges, a tagországok sokáig nem voltak hajlandók jelentős, a közösségi GDP-hez képest növekvő összegeket rendelni hozzájuk. Ez csökkentette a felhasznált összegek hatékonyságát, és hozzájárult ahhoz, hogy az egyenlőtlenségek több dimenziója a mai napig fennmaradjon, sőt növekedjen a jelenleg még 28 tagú EU munkaerőpiacán. A 2014-2020-as programperiódusban megemelték az ESzA-ra allokált összeget, ám ez sem jelentette, hogy a közösségi költségvetésen belül megnőtt volna annak súlya. A költségvetési fegyelem mindenekfelett álló szigorítása a vállalkozások versenyképességét segítő adócsökkentési versennyel együtt nem is teszi lehetővé a szociális és munkaerőpiaci kiadások jelentős növelését.

Körképünkből kitűnik, hogy az EU munkaerőpiaca az elmúlt évtizedekben jelentősen differenciálódott, megjelentek, illetve megerősödtek a különböző okok miatt bizonytalan és kiszolgáltatott helyzetben levő társadalmi rétegek. Aggasztó, hogy a közösségi politikák nem tudták ezek kialakulását és súlyát megakadályozni, illetve csökkenteni. A munkaadók álláspontja, a migrációval járó problémák, az EU-n belül kiéleződő tagországi ellentétek, a többsebességes EU lehetőségének felmerülése, a Brexit és a még mindig fenyegető Grexit stb. tükrében a jelenlegi helyzet sem utal arra, hogy a közeljövőben bekövetkezhetnének olyan változások, amelyek képesek lehetnek megfordítani az európai társadalmakat „aláásó” munkaerőpiaci tendenciákat.

\section{Irodalom}

ALDERMAnOCT, L. [2017]: Europe's on-demand economy draws complaints and regulators. The New York Times. 1 October. https://www.nytimes.com/2017/10/01/business/uber-economyeurope.html

ARTNER A. [2013a]: A fiatalok munkanélküliségének kérdéséhez Európa példáján keresztül. Közgazdasági Szemle. LX. évf. December. 1370-1392. old.

ARTNER, A. [2013b]: Is youth unemployment really the major worry? Debatte: Journal of Contemporary Central and Eastern Europe. Vol. 21. No. 2-3. pp. 183-205. https://doi.org/10.1080/ 0965156X.2013.863998

Statisztikai Szemle, 96. évfolụam 4. szóm 341-374. oldal 
ArTNER, A. [2014]: Youth unemployment and NEETs - Reasons and treatment in Europe with special regard to Hungary. In: Hishow, O. (ed.): Labour Market Trends in Bulgaria and the CEE Region - Overview and Perspectives. Economic Policy Institute. Sofia. pp. 119-159.

Az Európai Unió Hivatalos Lapja [2007]: Lisszaboni Szerződés az Európai Unióról szóló szerződés és az Európai Közösséget létrehozó szerződés módosításáról, amelyet Lisszabonban, 2007. december 13-án írtak alá. 50. évf. C 306. 2007. 12. 17. 1-271. old.

Az Európai Unió Hivatalos Lapja [2013]: Az Európai Parlament és a Tanács 1304/2013/EU rendelete (2013. december 17-én) az Európai Szociális Alapról és az 1081/2006/EK tanácsi rendelet hatályon kívül helyezéséröl. 56. évf. L 347. 2017. 12. 20. 470-486. old. https://doi.org/ 10.3000/19770731.L_2013.347.hun

BlitZ, R. [2016]: UK to have $1 \mathrm{~m}$ agency workers by 2020. Financial Times. 5 December. https://www.ft.com/content/ff371b92-ba32-11e6-8b45-b8b81dd5d080

BundeSAgENTUR FÜR ARBEIT STATISTIK [2018]: Beschäftigung - Die aktuellen Entwicklungen in Kürze. https://statistik.arbeitsagentur.de/Navigation/Statistik/Statistik-nach-Themen/ Beschaeftigung/Beschaeftigung-Nav.html

Carone, G. - Eckefeldt, P. - Giamboni, L. - Laine, V. - Sumner, S. P. [2016]: Pension Reforms in the EU Since the Early 2000's: Achievements and Challenges Ahead. European Commission, Directorate-General for Economic and Financial Affairs. Discussion Paper. No. 042. 16 December. Brussels. https://doi.org/10.2765/620267

Clark, K. B. - Summers, L. [1978]: The Dynamics of Youth Unemployment. NBER Working Paper Series. No. 274. https://doi.org/10.3386/w0274

COMMISSION OF THE EuROPEAN COMMUNITIES [1990]: Charter of the Fundamental Social Rights of Workers. Luxembourg. http://aei.pitt.edu/4629/1/4629.pdf

Da Silva, A. D. - Turrini, A. [2015]: Precarious and Less Well-paid? Wage Differences Between Permanent and Fixed-term Contracts Across the EU Countries. Economic Papers. No. 544. February. https://doi.org/10.2765/76353

DE LA PORTE, C. - HeINS, E. [2015]: A new era of European integration? Governance of labour market and social policy since the sovereign debt crisis. Comparative European Politics. Vol. 13. No. 1. pp. 8-28. https://doi.org/10.1057/cep.2014.39

DE la Porte, C. - JaCobsson, K. [2012]: Social investment or recommodification? Assessing the employment policies of the EU member states. In: Morel, N. - Palier, B. - Palme, J. (eds.): Towards a Social Investment Welfare State? Ideas, Policies and Challenges. Policy Press. Bristol. pp. $117-152$.

Dubois, H. [2016]: The Changing Meaning of "Working Age". European Commission. http://ec.europa.eu/social/main.jsp?langId=en\&catId=1196\&newsId=2500\&furtherNews=yes

Duell, N. [2004]: Defining and Assessing Precarious Employment in Europe: A Review of Main Studies and Surveys. Discussion Paper. December. Economix, Research \& Consulting. Munich. http://www.economix.org/pdf/ECONOMIXanalysis-precarious-employment-Europe.pdf

EC (European Commission) [2007]: European Social Fund. 50 Years Investing in People. Office for Official Publications of the European Communities. Luxembourg. http://ec.europa.eu /employment_social/esf/docs/50th_anniversary_book_en.pdf

EC [2016]: Employment and Social Developments in Europe 2015. Publications Office of the European Union. Luxembourg. https://doi.org/10.2767/950897

Statisztikai Szemle, 96. évfolụam 4. szóm 341-374. oldal 
EC [2017a]: Reflection Paper on the Social Dimension of Europe. Publications Office of the European Union. Luxembourg. https://doi.org/10.2775/51865

EC [2017b]: First Results. Public Opinion in the European Union. Standard Eurobarometer 87. Spring. http://ec.europa.eu/commfrontoffice/publicopinion/index.cfm/Survey/getSurveyDetail/ instruments/STANDARD/surveyKy/2142

EC [2018a]: Ameco online. http://ec.europa.eu/economy_finance/ameco/user/serie/SelectSerie.cfm

EC [2018b]: European Structural and Investment Funds. Data. https://cohesiondata.ec.europa.eu/

EC - GOS (Government OfFICES OF SwEDEN) [2017]: Concluding Report. Summit for Fair Jobs and Growth. 17 November. Gothenburg. http://www.government.se/4933fd/contentassets/ 70800fb59e6c43829c115ca73fb94b6e/concluding-report-gothenburg-summit.pdf

EP (European Parliament) [2016]: Precarious Employment in Europe. Part 1: Patterns, Trends and Policy Strategies. July. https://doi.org/10.2861/820746

EP (EuRÓPAi PARlAMENT) - TANÁCs (EuRÓPAi Unió TANÁCSA) - EB (EuRÓPAi BizotTSÁG) [2017]: A szociális jogok európai pillére. Az Európai Unió Kiadóhivatala. Luxemburg. https://doi.org/10.2792/115709

EU (European Union) [2010]: Youth on the Move. An Initiative to Unleash the Potential of Young People to Achieve Smart, Sustainable and Inclusive Growth in the European Union. Publications Office of the European Union. Luxembourg. https://doi.org/10.2766/69901

EU [2016]: Urban Europe - Statistics on Cities, Towns and Suburbs. 2016 Edition. Publications Office of the European Union. Luxembourg. https://doi.org/10.2785/594675

EuROFOund [2017a]: Exploring Self-Employment in the European Union. Publications Office of the European Union. Luxembourg. https://doi.org/10.2806/495400

EuROFOund [2017b]: Working Conditions of Workers of Different Ages. European Working Conditions Survey 2015. Publications Office of the European Union. Luxembourg. https://doi.org/10.2806/879475

EuROFOUND [2018]: Employed Persons Exposed to Employment-Related Physical, Psychological or Sexual Violence in the Last 12 Months by Sex and Age. Online database. https://data.europa.eu/euodp/data/dataset/4Fz1BBml239leVyJEsB0A

Eurostat [2015]: People in the EU - Statistics on an Ageing Society. http://ec.europa.eu /eurostat/statistics-explained/index.php/People_in_the_EU_\%E2\%80\%93_ statistics_on_an_ageing_society\#Main_tables

Eurostat [2018a]: Duration of Working Life - Annual Data. Online database. http://appsso.eurostat.ec.europa.eu/nui/show.do?dataset=lfsi_dwl_a\&lang=en /

Eurostat [2018b]: Employment and Activity by Sex and Age - Annual Data. Online database. http://appsso.eurostat.ec.europa.eu/nui/show.do?dataset=lfsi_emp_a\&lang=eng

Eurostat [2018c]: Population by Sex, Age, Citizenship and Labour Status (1 000). Online database. http://ec.europa.eu/eurostat/en/web/products-datasets/-/LFSA_PGANWS

Eurostat [2018d]: Healthy Life Years (From 2004 Onwards). Online database. http://appsso.eurostat.ec.europa.eu/nui/show.do?dataset=hlth_hlye\&lang=en

Eurostat [2018e]: Population on 1 January by Age and Sex. Online database. http://appsso.eurostat.ec.europa.eu/nui/show.do?dataset=demo_pjan\&lang=en

Eurostat [2018f]: Unemployment by Sex and Age - Annual Average. Online database. http://appsso.eurostat.ec.europa.eu/nui/show.do?dataset=une_rt_a\&lang=en 
Eurostat [2018g]: Employment by Sex, Age and Citizenship (1000). Online database. http://appsso.eurostat.ec.europa.eu/nui/show.do?dataset=lfsa_egan\&lang=en

Eurostat [2018h]: Young People Neither in Employment Nor in Education and Training by Sex, Age and Labour Status (NEET Rates). Online database. http://appsso.eurostat.ec.europa.eu /nui/show.do?dataset=yth_empl_150\&lang=en

Eurostat [2018i]: Precarious Employment by Sex, Age and NACE Rev. 1.1 Activity, and Rev. 2 Activity. Online database. http://appsso.eurostat.ec.europa.eu/nui/show.do?dataset=lfsa_qoe_4ax1 r1\&lang=en, http://appsso.eurostat.ec.europa.eu/nui/show.do?dataset=lfsa_qoe_4ax1r2\&lang=en

Eurostat [2018j]: Temporary Employment Agency Workers by Sex, Age and NACE Rev. 1.1 Activity, and Rev. 2 Activity. Online database. http://appsso.eurostat.ec.europa.eu/nui/show. do?dataset=lfsa_qoe_4a6r1\&lang=en,

http://appsso.eurostat.ec.europa.eu/nui/show.do?dataset=lfsa_qoe_4a6r2\&lang=en

Eurostat [2018k]: Full-Time and Part-Time Employment by Sex, Age and Educational Attainment Level (1 000). Online database. http://appsso.eurostat.ec.europa.eu/nui/show.do?dataset=lfsa_e pgaed\&lang=en

Eurostat [20181]: Involuntary Part-Time Employment as Percentage of the Total Part-Time Employment, by Sex and Age (\%). Online database. http://appsso.eurostat.ec.europa.eu /nui/show.do?dataset=lfsa_eppgai\&lang=en

EuRostat [2018m]: Temporary Employees by Sex, Age and Educational Attainment Level (1 000). Online database. http://appsso.eurostat.ec.europa.eu/nui/show.do?dataset=lfsa_etgaed\&lang=en

Eurostat [2018n]: Employed Persons Having a Second Job by Sex and Educational Attainment Level (1 000). Online database. http://appsso.eurostat.ec.europa.eu/nui/show.do?dataset=lfsa_ e2ged\&lang=en

Eurostat [2018o]: Self-Employment by Sex, Age and Educational Attainment Level (1 000). Online database. http://appsso.eurostat.ec.europa.eu/nui/show.do?dataset=lfsa_esgaed\&lang=en

Eurostat [2018p]: Average Number of Usual Weekly Hours of Work in Main Job, by Sex, Professional Status, Full-Time/Part-Time and Economic Activity (1983-2008, NACE Rev. 1.1) and (from 2008 Onwards, NACE Rev. 2) - Hours. Online database. http://appsso.eurostat.ec. europa.eu/nui/show.do?dataset=lfsa_ewhuna\&lang=en, http://appsso.eurostat.ec.europa.eu/nui/ show.do?dataset=lfsa_ewhun2\&lang=en

Eurostat [2018q]: Work on Weekends by Sex, Age, Professional Status and Occupation. Online database. http://ec.europa.eu/eurostat/web/products-datasets/product?code=lfsa_qoe_3b3

EuROSTAT [2018r]: Persons Reporting Exposure to Risk Factors That Can Adversely Affect Mental Well-being by Sex, Age and Educational Attainment Level. Online database. http://appsso.eurostat.ec.europa.eu/nui/show.do?dataset=hsw_exp1\&lang=en

EuROSTAt [2018s]: Self-Reported Work-Related Health Problems and Risk Factors - Key Statistics. Online database. http://ec.europa.eu/eurostat/statistics-explained/index.php?title=Self-reported_ work-related_health_problems_and_risk_factors_-_key_statistics\&redirect=no

Eurostat [2018t]: Persons Reporting Exposure to Risk Factors That Can Adversely Affect Physical Health by Sex, Age and Size of Enterprise. Online database. http://appsso.eurostat.ec. europa.eu/nui/show.do?dataset=hsw_exp10\&lang=en

Eurostat [2018u]: In-Work At-Risk-of-Poverty Rate by Age and Sex-EU-SILC Survey. Online database. http://appsso.eurostat.ec.europa.eu/nui/show.do?dataset=ilc_iw01\&lang=en

Statisztikai Szemle, 96. évfolụam 4. szóm 341-374. oldal 
EuROSTAT [2018v]: At-Risk-of-Poverty Rate by Poverty Threshold, Age and Sex-EU-SILC Survey. Online database. http://appsso.eurostat.ec.europa.eu/nui/show.do?dataset=ilc_li02

EUROSTAT [2018x]: Europe 2020 Strategy. http://ec.europa.eu/eurostat/web/europe-2020-indicators Eurostat [2018z]: People at Risk of Poverty or Social Exclusion by Age and Sex. Online database. http://appsso.eurostat.ec.europa.eu/nui/show.do?lang=en\&dataset=ilc_peps01

Eurostat [2018y]: GDP and Main Components (Output, Expenditure and Income). Online database. http://appsso.eurostat.ec.europa.eu/nui/show.do?dataset=nama_10_gdp\&lang=en

HÁRs Á. [2010]: Atipikus foglalkoztatási formák nemzetközi összehasonlitása statisztikák alapján. TÁMOP - 2.3.2-09/1. Mühelytanulmányok. No. T/3. November. Budapest.

HÁRs Á. [2013]: Atipikus foglalkoztatási formák Magyarországon a kilencvenes és a kétezres években. Közgazdasági Szemle. LX. évf. Február. 224-250. old.

HAtFiELD, I. [2015]: Self-Employment in Europe. IPPR Report. January. Institute for Public Policy Research. https://www.ippr.org/files/publications/pdf/self-employment-Europe_Jan2015.pdf

KBS (Kemmy Business SchoOL) [2017]: A Study on the Prevalence of Zero Hours Contracts Among Irish Employers and Their Impact on Employees, 2015. University of Limerick. https://www.labour.ie/download/pdf/studyontheprevalenceofzerohourscontracts.pdf

Letourneux, V. [1998]: Precarious Employment and Working Conditions in Europe. Office for Official Publications of the European Communities. Luxembourg. https://www.eurofound. europa.eu/sites/default/files/ef_files/pubdocs/1998/15/en/1/ef9815en.pdf

MAJOR, K. [2016]: Uber's happy go lucky drivers never existed - it was exploitation from the start. Independent. 28 October. http://www.independent.co.uk/voices/uber-drivers-employmenttribunal-never-existed-a7385691.html

Marcegaglia, E. [2017]: Speech at the Tripartite Social Summit. 18 October. https://www.businesseurope.eu/sites/buseur/files/media/speeches/2017-10-18_tss_speech_ emma_final.pdf

McKay, S. - JefFerys, S. - Paraksevopoulou, A. - Keles, J. [2012]: Study on Precarious Work and Social Rights. Final report. No. VT/2010/084. Working Lives Research Institute, London Metropolitan University. http://www.bollettinoadapt.it/old/files/document/21184londonmet_ 042012.pdf

O'Higgins, N. [1997]: The Challenge of Youth Unemployment. Action Programme on Youth Unemployment, Employment and Training. International Labour Office. Geneva. https://doi.org/10.1111/j.1468-246X.1997.tb01084.X

O'Higgins, N. [2001]: Youth Unemployment and Employment Policy: A Global Perspective. MPRA Paper. No. 23698. 10 July. International Labour Organization. Geneva. http://mpra.ub.uni-muenchen.de/23698/1/MPRA_paper_23698.pdf

OECD (ORgANiSATION FOR ECONOMIC CO-OPERATION AND DEVElOPMENT) [2017]: Understanding the Socio-Economic Divide in Europe. Background Report. 26 January. https://www.oecd.org /els/soc/cope-divide-europe-2017-background-report.pdf

Official Journal of the European Communities [2000]: Charter of fundamental rights of the European Union. Vol. 43. C 364. 18. 12. 2000. pp. 1-22. http://www.europarl.europa.eu /charter/pdf/text_en.pdf 
ONS (OfFice fOR NATIONAl Statistics) [2017]: Labour Force Survey: Zero-Hours Contracts Data Tables. Online dataset. https://www.ons.gov.uk/employmentandlabourmarket/people inwork/earningsandworkinghours/datasets/zerohourssummarydatatables

OsBorne, H. [2016]: CitySprint faces tribunal over rights of freelance workers. The Guardian. 22 November. https://www.theguardian.com/business/2016/nov/22/citysprint-faces-tribunal-overtreatment-of-freelance-workers

SCARPETtA, S. - Sonnet, A. - MANFredi, T. [2010]: Rising Youth Unemployment During the Crisis: How to Prevent Negative Long-Term Consequences on a Generation? OECD Social, Employment and Migration Papers. No. 106. http://dx.doi.org/10.1787/5kmh79zb2mmv-en

WHITE, C. [2014]: Are "mini-jobs" a responsible substitute for Canada's temporary foreign workers? Scotiabank Economics. 15 August. http://www.gbm.scotiabank.com/English/bns_econ/minijobs.pdf

\section{Summary}

Based on statistical data, the article gives an overview of those changes in the EU labour market that have taken place especially since the turn of the millennium. The author examines not only the trends of employment and unemployment, but also the evolution of atypical employment forms, and the dimensions of poverty. In addition, the development of the EU social and employment policy is presented and set against the labour market developments. It is concluded that the EU labour market has considerably differentiated over the last decades and as the atypical forms of employment are spreading, a sometimes latent, in other cases clearly tangible social stratum has appeared that suffers from uncertainty, vulnerability and poverty. The EU common policies have been able to moderate so far but could not stop the deterioration of the European labour market, which is apparently negligible, although alarming. 